\title{
A Review of Seaweed Pre-Treatment Methods for Enhanced Biofuel Production by Anaerobic Digestion or Fermentation
}

\author{
Supattra Maneein *, John J. Milledge ${ }^{\circledR}$, Birthe V. Nielsen $($ and Patricia J. Harvey $₫$ \\ Faculty of Engineering and Science, Algae Biotechnology Research Group, University of Greenwich, \\ Central Avenue, Chatham Maritime, Kent ME4 4TB, UK; J.J.Milledge@gre.ac.uk (J.J.M.); \\ B.V.Nielsen@greenwich.ac.uk (B.V.N.); P.J.Harvey@greenwich.ac.uk (P.J.H.) \\ * Correspondence: s.maneein@gre.ac.uk; Tel.: +44-208-331-8871
}

Received: 2 November 2018; Accepted: 27 November 2018; Published: 29 November 2018

\begin{abstract}
Macroalgae represent a potential biomass source for the production of bioethanol or biogas. Their use, however, is limited by several factors including, but not restricted to, their continuous supply for processing, and low biofuel yields. This review examines recent pre-treatment processes that have been used to improve the yields of either biogas or bioethanol from macroalgae. Factors that can influence hydrolysis efficiency and, consequently, biofuel yields, are highly affected by macroalgal composition, including content of salts, heavy metals, and polyphenols, structural make-up, as well as polysaccharide composition and relative content of carbohydrates. Other factors that can influence biofuel yield include the method of storage and preservation.
\end{abstract}

Keywords: macroalgae; bioethanol; biogas; hydrolysis

\section{Introduction}

In 2016, 29 million tonnes (wet-weight) of red, brown, and green macroalgae, also known as seaweeds, were harvested mainly for human food, animal feed, and production of hydrocolloids [1,2]. This represents a 39\% increase since just 2014. It has also been accompanied by a commensurate surge in research interest in the use of both micro- and macro-algae as a source of biofuel, due to the high potential yields of these sources of biomass and growth systems that do not compete for agricultural land and fresh water [3-6]. Saccharina japonica, for example, was found to be 6.5 times more productive than sugarcane based on the maximum cultivated yields predicted in tonnes per hectare per year (wet-weight) [7].

Biofuel in the form of biogas from seaweed could help to reduce greenhouse gas (GHG) emissions by $42-82 \%$ compared to the use of natural gas [8,9], and contribute to achieving the EU targets by 2030: namely, total renewable energy share of $27 \%$ and reduced GHG emissions by $40 \%$ of the 1990 levels [10]. Moreover, the European Parliament has indicated that seaweed, as well as other types of waste, should contribute to at least $1.25 \%$ of energy consumption in the transportation sector by 2020 [11].

However, high water content $(80-90 \%)$ of seaweed impacts negatively on the energy balance of applications that depend on dry biomass [6]. This makes seaweed undesirable for direct combustion, pyrolysis, and gasification, but suitable for processes that can produce net energy gain based on the use of wet biomass $[12,13]$. These methods include hydrothermal liquefaction for bio-oil production; fermentation for ethanol production, and anaerobic digestion (AD) for biogas production [14]. All three methods are still under development for the production of biofuel from seaweed [14]. Details on hydrothermal liquefaction of seaweed can be found in Milledge et al. (2014) [14] and Liu et al. (2013) [15]. 
This review will focus on fermentation and AD of seaweed, because seaweed has the potential to replace energy crops competing with food as a biofuel feedstock in the existing ethanol and biogas production infrastructures [16]. Gross energy yields derived from AD of Saccharina latissimi, for example, could reach up to 365 GJ per hectare per year [17], bearing similarities with biogas yields from maize (59-436 GJ per hectare per year), a widely used AD feedstock [18]. For fermentation and ethanol distillation, energy return on investments (EROI) for seaweed (0.44 to 1.37 in a highly efficient processing system of seaweed) can be similar to maize (1.07) [19]. In terms of their sustainability, the EnAlgae project concluded that seaweed could be cultivated with a comparable life cycle resource demand to several land plants [20]. Processes that use the entire biomass rather than just the fermentable sugars have more favourable EROIs [21] with seaweed biogas production having an EROI of 2.4, and combined production of biogas and bioethanol from seaweed having an EROI of 3.0 or greater, an EROI of 3 being the minimum value for a sustainable and viable processing system for fuel production [22]. However, the current practical yields of biogas from AD of seaweed can be as low as $79 \%$ below the theoretical maximum [23]. Low values below the theoretical maximum are also shown for ethanol yields [24].

Figure 1 provides a schematic of the biochemical processes involved in producing either biogas (Figure 1A) or bioethanol (Figure 1B). In both cases, the first stage of production requires hydrolysis of polysaccharides to sugars. In the case of biogas production, sugars from hydrolysed polysaccharides are converted to acetate, $\mathrm{CO}_{2}$ and $\mathrm{H}_{2}$ by natural microbial processes termed acidogenesis and acetogenesis, and thence to methane and $\mathrm{CO}_{2}$ by methanogenesis [25]. For ethanol production, glucose and galactose from the hydrolysis of the major polymers in seaweed i.e., cellulose; starch, and ulvan (green seaweed); carrageenan and agar (red seaweed), and laminarin and fucoidan (brown seaweed), along with glucuronic acid and mannitol (brown seaweed) are converted by natural microbial processes to pyruvate by glycolysis in anaerobic respiration, thence to ethanol and $\mathrm{CO}_{2}$ by alcoholic fermentation [25]. Unlike AD processing [26], there is a lack of natural microbial communities that can efficiently utilise fucose, rhamnose, xylose, and uronic-, and mannuronic-acid for alcohol fermentation [27-30], but metabolic engineering is increasingly facilitating the conversion of these latter sugars to pyruvate for alcoholic fermentation [11]. An in-depth review of the utilisation and conversion of these substrates to bioethanol by microorganisms can be found by Kawai and Murata (2016) [31].

Pre-treatments of biomass that modify the bioavailability of polysaccharides for their hydrolysis to sugars could have a major impact on both rate and yields of biogas or ethanol [32], enabling higher biofuel production in a given time. Methane yields, for example, have been improved by $19 \%-68 \%$ after the breakdown of biomass structures by mechanical, thermal, enzymatic, and chemical treatments to improve cellular access to polysaccharide-hydrolysing agents [33]. Since AD and fermentation are both dependent on the activities of microbial communities, optimisation of operating conditions to support their respective rates of microbial catalysis will also improve biofuel yields [34]. For example, by extending the solids retention time during AD, agar was hydrolysed to shorter chains and became a suitable substrate [35], possibly due to the adaptation of microorganisms [36]. The source of inoculum used can also be important where microbes can be affected by salt concentrations in seaweed [37], which may influence hydrolysis efficiency. These factors can affect methane yields when the inoculum is not acclimatised [34,38].

In the last decade, there have been continuing efforts to optimise pre-treatments to achieve better yields and lower costs. An in-depth review of the mechanisms of different pre-treatment methods, focusing on microalgae rather than seaweed, can be found in a review by Rodriguez et al. (2015) [39]. Pre-treatment options for the production of liquid biofuels have been briefly discussed by Wei, Quarterman, and Jin (2013) [16]. The process hurdles of both harvesting and post-harvest treatment of seaweed have been briefly discussed by Milledge and Harvey (2016) [6]. Jung et al. (2013) [40] have also briefly reviewed characteristics of different seaweed, highlighted microorganisms capable of hydrolysing seaweed carbohydrates, and different hydrolysis treatments developed to 
produce bioethanol from seaweed. See also Michalak (2018) [41], who reviewed the experimental processing of seaweed for the production of various biofuels. However, to the authors' knowledge, there are no studies conducted to comprehensively review pre-treatment methods of seaweed for utilisation in AD or fermentation. This makes the selection of the appropriate pre-treatment method for seaweeds difficult.
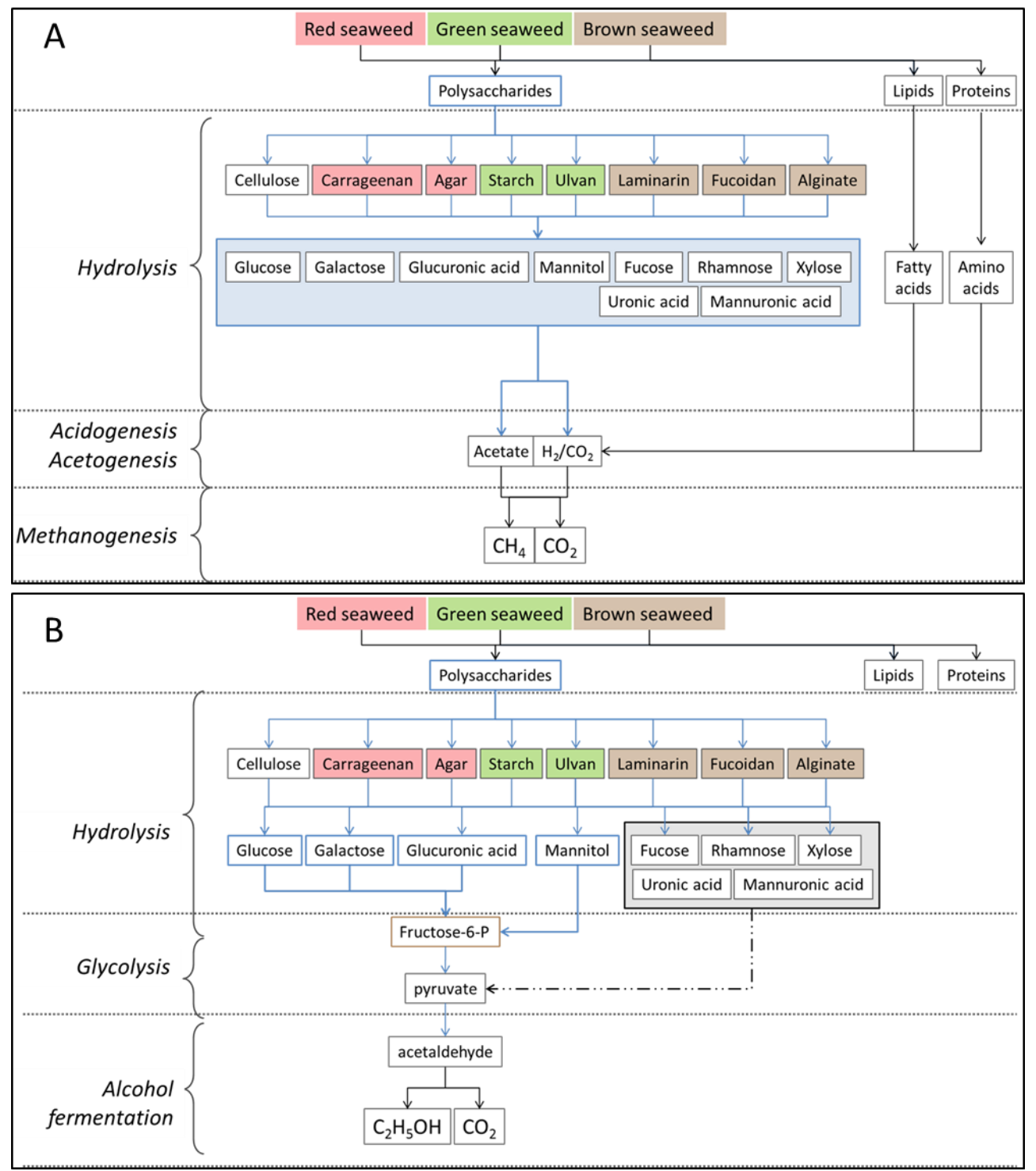

Figure 1. Major steps for biogas production (A), or ethanol production (B) from harvested seaweed. Polymeric cellulose, lipids, and proteins are found in all red, green and brown seaweeds. Additionally, the polymeric polysaccharides carrageenan and agar, colour-coded red, are typical of red seaweeds; starch and ulvan, colour-coded green, typical of green seaweeds, and laminarin, fucoidan, and alginate, colour-coded brown, typical of brown seaweeds. See also Wei, Quarterman and Jin (2013) [16].

In this review, pre-treatments will refer to the downstream processing steps of seaweed after harvesting and before AD or fermentation, which are suitable for improving biofuel yields at industrial scales. To set the scene, an overview of the chemical and structural composition of different seaweeds precedes methods for their pre-treatment, including its storage and preservation. Different methods recently utilised to break down seaweed into less complex substrates for improved hydrolysis of their polysaccharides are emphasised. Intrinsic inhibitors or those formed after pre-treatments that can limit biofuel yields and its commercialisation are also discussed. 


\section{Structural and Chemical Composition}

\subsection{Moisture and Salt Content}

Seaweeds have a higher water content than many terrestrial crops [6]. The higher heating value (HHV) of seaweeds is lower than terrestrial energy crops due to the high ash content of the former [42]; higher calorific values have been achieved in seaweeds that have been demineralised [43]. Seaweed also has a higher salt (sodium chloride) content than terrestrial plants, with salt being $15 \%$ dry weight (DW) of unwashed Sargassum muticum [44].

\subsection{Structural Composition}

Structural differences exist between the red, green, and brown seaweed. A review by Kloareg and Quatrano (1988) thoroughly underlines these differences [45]. Briefly, the primary skeletal cell wall component in brown seaweed is cellulose, while xylan, mannan, and cellulose are found in green and red seaweed $[45,46]$. Notably, green and red seaweeds have been found solely with crystalline xylan and mannan forming the skeletal backbone, which can also change with the growth of the seaweed [45]. These polysaccharides form microfibrils which have different structural configurations, where cellulose and mannans are characterised by flat ribbons, while xylans are in a helix configuration [45]. These microfibrils have variable orientations depending on the species, either having an organised structure or being randomly distributed within each layer [47].

Furthermore, these microfibrils are associated with matrix polysaccharides which include different sulphated or carboxylic polysaccharides depending on the species (Table 1) [48]. For example, sulphated fucans were suggested to play a role in 'interlocking' the cellulosic backbone [49]. In brown seaweed, proteins were also found associated with sulphated fucans and phenols [49]. The attachment between phenols and alginates are likely to play an important role in the rigidity of cell wall structures [49]. Additionally, phenols can also be inhibitory to microorganisms involved in biofuel production, as will be discussed in later sections. The structural overview of cell walls in green and brown seaweed are shown in Figure 2.
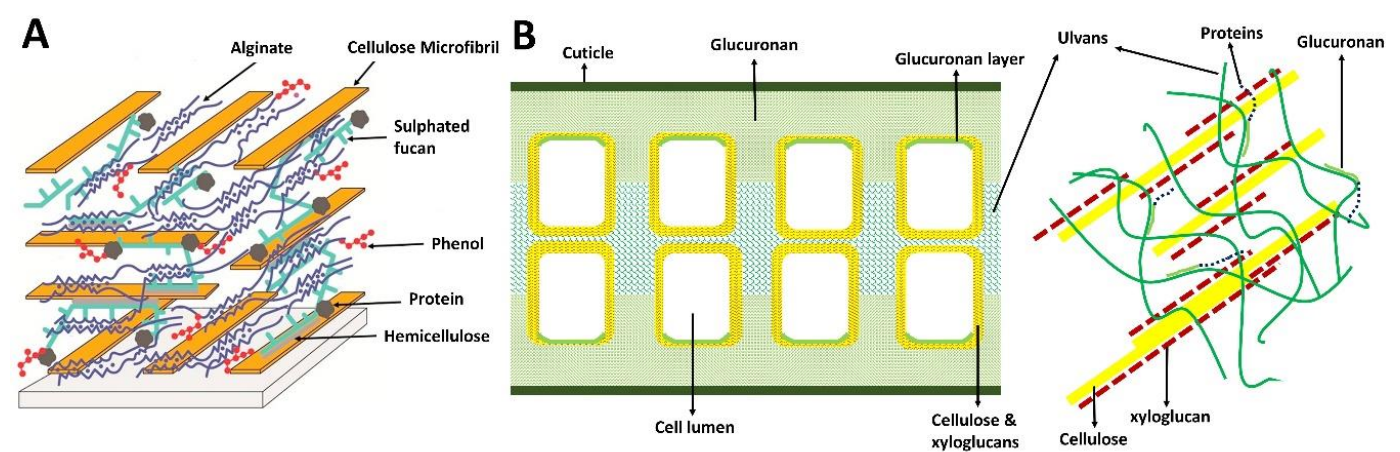

Figure 2. (A) Cell wall model of brown seaweed (Fucales) [50], modified for simplification (obtained permission for re-use). (B) Cell wall polysaccharide distribution of green seaweed (Ulva spp.); far right figure shows closer interactions between polysaccharides, adapted from Lahaye and Robic (2007) [51]. Reprinted with the permission of the American Chemical Society.

Ulvans found in green seaweeds, comprised of xylose, rhamnose, uronic acid, and galactose, are relatively resistant to degradation. They may, therefore, act to limit access to, and biodegradation of, other polysaccharides, especially cellulose and starch [52]. Bobin-Dubigeon et al. (1997) [52] suggested similar roles of alginates in brown seaweeds and carrageenans in red. Thus, the use of alginate lyase to break down brown seaweed was found to release only small amounts of sulphated fucans [49], whilst effects of cellulase and alginate lyase treatment of Laminaria digitata were insignificant on biogas yields [53]. Cell wall architecture in seaweeds may, therefore, be similar to that of the plant cell wall in land-plants: chains of $\beta-1,4-$ linked glucose molecules in crystalline cellulose microfibrils provide 
structural support but are protected from hydrolysis to glucose by most natural microorganisms, in the case of seaweeds, by a matrix of sulphated fucans and alginates in brown seaweeds, carrageenans and agar in red, and ulvans in green seaweeds [52], and in land-plants, by polymeric lignin.

Sargassum spp., a brown seaweed, is more recalcitrant to digestion compared to Gracilaria spp., a red seaweed, and Ulva spp., a green seaweed [35]. The insoluble fibre content in brown seaweed has been found to vary greatly in different seasons, with total fibre content ranging from 36-54\% in Hizikia Fusiformis [54]. A general overview of fibre content in two different studies suggests that brown seaweed may generally have a higher fibre content $(10 \%-75 \%)$ compared to red $(10 \%-59 \%)$ or green $(29 \%-67 \%)$ seaweed $[55,56]$. Consequently, pre-treatment methods may need to be tailored depending on the seaweed type and structural composition.

\subsection{Polysaccharides}

The suitability of different types of pre-treatment for processing seaweed is likely to vary with differences in seaweed chemical composition [57,58]. Chemical profiling of 107 seaweed types showed many similarities between different seaweed groups [59], with red and green seaweed having more similar characteristics in their water-soluble and insoluble components compared to brown seaweed, which held more unique characteristics [59]. However, clear distinctions between them are found in their sugar and amino acid compositions [60].

The polysaccharides and sugars in different types of seaweeds and their unique characteristics are shown in Table 1. The structures of these polysaccharides were highlighted by Wei, Quarterman, and Jin (2013) [16]. Seaweeds generally have high sulphur content due to the presence of sulphated polysaccharides with different amounts of sulphate groups in different polysaccharides, which also varies in different phyla and genera [61,62], where brown seaweed contain sulphated fucans [63]; red seaweed contains sulphated galactans (agar and carrageenan); and green seaweed contains sulphated xyloarabinogalactans or other sulphated heteropolysaccharides, depending on the species [62]. It should be noted that this is highly simplified and more detailed work can be found by Kloareg and Quatrano (1988) [45] and Synytsya et al. (2015) [48].

Table 1. Sugars and polysaccharides in red, green, and brown seaweed.

\begin{tabular}{|c|c|c|c|}
\hline Seaweed Type & Polysaccharides & Sugars & Ref. \\
\hline Red & $\begin{array}{l}\text { Agar }{ }^{1} \text {, carrageenan }{ }^{1} \text {, agaropectin, } \\
\text { cellulose, xylans, mannans }\end{array}$ & $\begin{array}{l}\text { D-galactose, D-fructose, } \\
\text { 3,6-anhydro-D-galactose, } \\
\text { glucose }\end{array}$ & {$[45,60,64]$} \\
\hline Green & $\begin{array}{c}\text { Ulvan }^{1} \text {, starch, xylopyranose, } \\
\text { glucopyranose, xyloglucan, glucuronan, } \\
\text { cellulose, hemicellulose }\end{array}$ & $\begin{array}{l}\text { Glucose, xylose, uronic acids, } \\
\text { rhamnose, galactose }\end{array}$ & {$[52,60]$} \\
\hline Brown & Fucoidan ${ }^{1}$, laminaran, alginates ${ }^{1}$, cellulose & $\begin{array}{l}\text { Mannitol, glucose, guluronate, } \\
\text { mannuronate, glucuronate, } \\
\text { sulphated fucose }\end{array}$ & {$[60,65,66]$} \\
\hline
\end{tabular}

The biochemical composition of seaweeds' polysaccharides influences their structural configurations and properties [67], with alginates described as egg-box like (Figure 2), carrageenans in a double helix, and ulvans in a bead-like configuration $[45,68]$. These differences are also likely to influence the effects of pre-treatments and biofuel yields. Alginic acid and its sodium salt were found to be recalcitrant to AD with average methane yields equivalent to only $23 \%-28 \%$ of their theoretical methane potential, considerably below that of cellulose [69].

\subsection{Chemical Composition Variability}

Seaweed composition varies between species, seasons, and geographical location due to differences in sea currents, light intensities, and temperatures [65]. The amino acid content in S. latissima in August 
was almost double that in June and ash and mineral contents also increased [70]. Polysaccharides, such as fucoidan, also show different degrees of branching, sulphation, and chain length at different times of the year [65]. Seaweeds growing in the presence of higher heavy metal contents also produced more cell wall polysaccharides [71]. Furthermore, phenolic compounds that are potential inhibitors of AD and fermentation (Section 4.5.2) also vary spatio-temporally in seaweeds [72].

\section{Storage and Preservation}

The combined effects of the seasonal growth of seaweeds and the fluctuations in levels of fermentable sugars present in seaweeds harvested in different seasons suggest there is only a small window for harvesting during the year to obtain the optimal biomass composition for biofuel production [73]. Therefore, in many geographical locations, there is a need for effective preservation methods if seaweed is to be used for biofuel production throughout the year.

\subsection{Drying for Storage}

Drying of seaweeds to a moisture content $<22 \%$ is recommended before storage [73]. This not only improves shelf life but can also reduce transportation costs [6]. Drying of seaweed can involve drying on platforms directly under the sun, in greenhouse drying facilities, or by using solar thermal drying systems that may also utilise electricity $[73,74]$. Methods that rely on solar energy would be less suitable and more energy consuming in temperate climates. Alternatively, to reduce energy consumption, Milledge and Harvey (2016) [6] have suggested mechanical dewatering to reduce moisture content before drying. However, screw-pressing brown seaweed has been found to be ineffective unless the seaweed is pre-treated with hydrochloric acid [75].

\subsection{Ensilage for Storage and Preservation}

Ensiling is a practice used in the production of forages from terrestrial crops to preserve wet biomass. Ensiling involves the biochemical conversion of water-soluble carbohydrates into mainly lactic acid and other organic acids by anaerobic microorganisms [6], creating a $\mathrm{pH}$ drop that prevents the growth of spoilage microorganisms [76]. For forages, the ideal conditions have been indicated as the following: at least $25 \% \mathrm{DW}$; high concentrations of water-soluble carbohydrates for lactic acid bacteria to initiate and sustain fermentation; at least $10^{6}$ colony forming units of lactic acid bacteria per gram of fresh biomass; and low buffering capacity to rapidly reduce the $\mathrm{pH}[58,76]$. A rapid drop in $\mathrm{pH}$ is required to prevent a cascade of $\mathrm{pH}$-increasing effects caused by the growth of clostridia, where clostridia utilise lactic acid and water-soluble carbohydrates, and produce butyric acid and $\mathrm{CO}_{2}$ [58].

However, seaweeds have high buffering capacity due to their high anionic acid content, with additional inoculation of lactic acid bacteria having mixed successes in lowering the $\mathrm{pH}$ for different seaweed species [58]. A pH of lower than 4.7 is required to prevent the growth of clostridia in Saccorhiza polyschides [76], while below pH 4.48-4.10 is sufficient for S. latissima [58]. Sandbakken et al. (2018) [77] found that no sugar loss was detected during 6 months of storage when S. latissima was stored anaerobically at a $\mathrm{pH}<4$ by the addition of sulphuric and formic acid.

Success in ensiling seaweed is also highly affected by the season of harvest and the seaweed species, which influences the biochemical composition of the biomass [58,76,78]. For example, high polyphenol content in Ascophyllum nodosum may contribute to low acid production by inhibiting fermentative microorganisms, thereby preventing a successful $\mathrm{pH}$ drop [76]. Pre-processing methods can also have significant effects on ensiling success. In washing treatments used prior to ensiling, different results for the HHV were found between the ensiled and non-ensiled seaweed: Redden et al. (2016) [78] found an increase (seawater washed); Herrmann et al. (2015) [76] found an increase (cold water washed); Cabrita et al. (2017) [58] found an increase (cold freshwater washed); and Milledge and Harvey (2016a) [44] found an insignificant difference in HHV (unwashed seaweed). The differences in washing could also play a role in the extent of inorganic and organic material loss during ensiling [78,79]. Additionally, maceration of biomass prior to ensilage, using a macerator, was shown to increase the fermentation rate and lactic acid 
concentration [80,81], as well as reduce ethanol production during ensilage [82]. By contrast, chopping of seaweed before ensilaging, which may form larger particle sizes and reduce the rate of hydrolysis compared to maceration, reduced overall leachate loss, loss of total solids (TS), and volatile solids (VS) [44], allowing more of the biomass to be available for further downstream processing.

Unsuccessful ensilaging of Gracilaria vermiculophylla has been partly attributed to its high water content [58], which could be reduced by dewatering before ensilaging. Dewatering techniques include screw-pressing, using chemical additives, saline solutions or salting [75,83]. Screw-pressing itself has been found to increase ethanol yields of Laminaria digitata [83]. However, these methods will also need to be selectively chosen for different types of seaweeds as it was found that red and brown seaweeds required different dewatering methods [57].

From literature searches, the production of ethanol from ensiled seaweed has received little attention. $\mathrm{AD}$ has thus far delivered mixed results: use of ensiled A. nodosum showed enhanced methane production compared to untreated A. nodosum, regardless of VS losses during storage and provided the leachate was also co-digested, but ensiling $S$. latissima had no significant effect on methane production and a negative effect for S. polyschides [76]. Milledge et al. (2018) [79] also found no significant difference between methane production from ensiled and fresh S. muticum. Further research is required to establish the conditions optimal for successful preservation of different seaweed types for non-seasonal use in biofuel production.

\section{Seaweed Hydrolysis Methods}

\subsection{Mechanical Treatment}

Mechanical pre-treatment to improve access by hydrolysing agents to polysaccharides mainly affects the physical structure of seaweeds. A summary of mechanical pre-treatments performed on seaweed before ethanol or methane production is shown in Tables 2 and 3. The range of mechanical pre-treatments includes size reduction, beating, washing, and sonication of seaweed. Direct comparison between each treatment and between different seaweeds by direct comparisons of percentage change in yields is difficult as various authors treat the biomass in diverse manners. This includes differences in enzymes used for saccharification, yeasts used for fermentation, inoculum to substrate (I/S) ratios, and the biochemical methane potential (BMP) measurement methods which can affect the final gas volume [84]. Methane yields are presented rather than biogas yields where possible due to variable methane composition $(<40 \%$ to $\sim 70 \%)$ depending on the feedstock and BMP test period $[85,86]$; with typical values around $60 \% \mathrm{CH}_{4}, 40 \% \mathrm{CO}_{2}$, and other trace gases [87].

The biodegradability index (BI) is used to indicate the efficiency of the particular pre-treatment approach relative to the theoretical yield [88], and is used to compare the effectiveness of the pre-treatments more easily. It is calculated by the methane or ethanol yield after pre-treatment divided by the authors' provided theoretical yield and presented as a percentage. The change in the biodegradability index (BI), similar to the \% change, is also used to indicate the effectiveness of the pre-treatment relative to the untreated control seaweed. Different methods were used to calculate theoretical yields: some authors have estimated the theoretical ethanol yield according to glucan content (0.57 g ethanol g ${ }^{-1}$ glucan) [89], while others have used glucose which includes hydrolysis gain (0.51 $\mathrm{g}$ ethanol $\mathrm{g}^{-1}$ glucose) [90]. Since glucose is often not the primary fermentable substrate, others have used laminarin and mannitol concentrations [91]. Ethanol yields have been converted to the same units where possible. Where authors had tested more than one variable, tables show the variables with the highest ethanol or methane yields. The tables cannot give a complete picture of the most effective pre-treatment method, but demonstrate the effectiveness of each pre-treatment method for the particular species harvested at a particular time of year, using a specific approach. 
Table 2. Ethanol yield following mechanical pre-treatment of seaweed.

\begin{tabular}{|c|c|c|c|c|c|c|c|}
\hline Algae (Harvest Time) & Pre-treatment & Fermentation & Ethanol Yield ( $\left.\mathrm{mg} \mathrm{g}^{-1} \mathrm{DW}\right)$ & $\%$ Change & BI (\%) & $\Delta B I *(\%)$ & Ref \\
\hline \multicolumn{8}{|c|}{ Size reduction } \\
\hline $\begin{array}{l}\text { Gelidium sesquipedale } \\
\text { (unknown time) }\end{array}$ & \multirow{2}{*}{$\begin{array}{l}\text { Freshwater washed and air-dried. } \\
\text { Test: Cutting milled then centrifugally milled, } 12,000 \mathrm{rpm} \text {. } \\
\text { Control: Cutting milled: }<2 \mathrm{~mm} .\end{array}$} & \multirow{2}{*}{$\begin{array}{l}\text { Simultaneous saccharification and fermentation (SSF): } \\
5 \% \text { seaweed loading fermented with Haliatase enzyme } \\
\text { ( } \beta \text {-glucanase, carragenase, agarase), and S. cerevisiae, } \\
\text { stirred }\left(37^{\circ} \mathrm{C}, 72 \mathrm{~h}(\mathrm{~h})\right)\end{array}$} & 351 & +80 & 69 & $+79.8^{1}$ & \multirow{2}{*}{92} \\
\hline $\begin{array}{c}\text { Ulva lactuca } \\
\text { (unknown time) }\end{array}$ & & & 527 & -4.4 & 64 & $-4.3^{1}$ & \\
\hline $\begin{array}{l}\text { Chaetomorpha linum } \\
\text { (September 2010) }\end{array}$ & $\begin{array}{c}\text { Freshwater washed, dried }\left(40^{\circ} \mathrm{C}, 48 \mathrm{~h}\right) \\
\text { Test: } 25 \mathrm{~g} \text { ball milled }(25 \text { balls), } 18 \mathrm{~h}, 180 \mathrm{rpm} \text { to }<2 \mathrm{~mm} \text { size. } \\
\text { Control: untreated biomass }\end{array}$ & $\begin{array}{l}\text { SSF: } 10 \% \text { pre-treated seaweed pre-hydrolysed, } \\
\text { inoculated: cellulase enzymes, and S. cerevisiae, } \\
\qquad 32^{\circ} \mathrm{C}, 200 \mathrm{~h}\end{array}$ & 180 & +63.6 & 77 & $+41.9^{2}$ & {$[89]$} \\
\hline \multicolumn{8}{|c|}{ Washing } \\
\hline \multirow{2}{*}{$\begin{array}{l}\text { L. digitata } \\
\text { (July 2009) }\end{array}$} & $\begin{array}{l}\text { Test: Freshwater washed (W) Oven dried (OD) }\left(70^{\circ} \mathrm{C}, 72 \mathrm{~h}\right) ; \\
\text { frozen }\left(-20^{\circ} \mathrm{C}\right) \text { and } \mathrm{OD}(\mathrm{FOD}) .\end{array}$ & \multirow{2}{*}{$\begin{array}{l}\text { SSF: } 5 \% \text { seaweed with laminarinase and yeast } \\
\text { Pichia angophorae stirred at } 24^{\circ} \mathrm{C}, 88 \mathrm{~h}\end{array}$} & $W+O D: 12.3 \mu \mathrm{L} \mathrm{g}^{-1} \mathrm{DW}$ & -9.6 & 19 & $+49.2^{3}$ & \multirow{2}{*}{91} \\
\hline & $\begin{array}{l}\text { Control: Unwashed, OD or FOD. } \\
\text { All milled to }<1 \mathrm{~mm} \text {. }\end{array}$ & & $W+F O D: 11.1 \mu \mathrm{L} \mathrm{g}^{-1} \mathrm{DW}$ & -26 & 15 & $-8.1^{3}$ & \\
\hline \multicolumn{8}{|c|}{ Sonication } \\
\hline $\begin{array}{c}\text { U. rigida } \\
\text { (unknown time) }\end{array}$ & \multicolumn{2}{|c|}{$\begin{array}{l}\text { Dried }\left(70^{\circ} \mathrm{C}, 48 \mathrm{~h}\right) \text {, ground: } \leq 1 \mathrm{~mm} \text { particle size. } \\
\text { SSF: } 4 \%(w / v) \text { seaweed, amyloglucosidase, } \alpha \text {-amylase, cellulase enzymes, buffer, and S. cerevisiae. } \\
\text { Test: Incubated in sonicator bath, } 40 \mathrm{kHz}, 120 \mathrm{~W}, 37^{\circ} \mathrm{C}, 3 \mathrm{~h} \text {. } \\
\text { Control: conventional incubator, } 150 \mathrm{rpm}, 37^{\circ} \mathrm{C}, 48 \mathrm{~h}\end{array}$} & $64.7^{4}$ & $+58.8^{4}$ & 65 & $-2.9^{5}$ & {$[90]$} \\
\hline
\end{tabular}

Table 3. Methane yields following mechanical pre-treatment of seaweed.

\begin{tabular}{|c|c|c|c|c|c|c|c|c|}
\hline Algae (Harvest Time) & Pre-treatment & I/S Ratio; Source & BMP Method & $\mathrm{CH}_{4}$ Yield (mL g $\left.{ }^{-1} \mathrm{VS}\right)$ & $\%$ Change & BI (\%) & $\Delta \mathrm{BI}(\%)$ & Ref. \\
\hline \multicolumn{9}{|c|}{ Size reduction } \\
\hline \multirow{3}{*}{$\begin{array}{l}\text { G. vermiculophylla } \\
\text { (March 2012) }\end{array}$} & \multirow{3}{*}{$\begin{array}{l}\text { Test: Unwashed and macerated (UM); } \\
\text { washed and macerated (WM); washed, } \\
\text { dried }\left(37^{\circ} \mathrm{C}\right) \text { and macerated (WDM). } \\
\text { Control: without maceration. }\end{array}$} & \multirow{3}{*}{$\begin{array}{l}4: 1 \text {; brewery wastewater } \\
\text { treatment plant (WWT) }\end{array}$} & \multirow{3}{*}{$\begin{array}{l}\text { Glass vials with rubber stopper, } \\
\text { aluminium crimp, } 37^{\circ} \mathrm{C}, 28 \text { days. }\end{array}$} & UM: 338 & +14.6 & - & - & \multirow{3}{*}{93} \\
\hline & & & & WM: 481 & +11.9 & - & - & \\
\hline & & & & WDM: 349 & +7.7 & - & - & \\
\hline G. vermiculophylla & \multirow{4}{*}{$\begin{array}{l}\text { Frozen at harvest (unknown time of harvest). } \\
\text { Test: Fresh water washed, macerated ( }(\mathrm{M}) \text {. } \\
\text { Control: Fresh water washed and chopped }(2 \times 2 \mathrm{~cm})\end{array}$} & \multirow{4}{*}{$\begin{array}{l}\text { 6:1 in } 500 \mathrm{~mL} \text {; } \\
\text { lab reactor using cattle manure }\end{array}$} & \multirow{4}{*}{$\begin{array}{l}\text { Bottles with rubber stoppers and } \\
\text { aluminium crimp, } 53^{\circ} \mathrm{C}, 34 \text { days }\end{array}$} & 147 & +11.4 & - & - & \multirow{4}{*}{94} \\
\hline C. linum & & & & 195 & +17.5 & - & - & \\
\hline U. lactuca & & & & 255 & +67.7 & - & - & \\
\hline S. latissima & & & & 333 & -2.1 & - & - & \\
\hline \multirow{2}{*}{$\begin{array}{l}\text { Laminaria spp. } \\
\text { (November 2013) }\end{array}$} & $\begin{array}{l}\text { Test: Ball milled ( } 20 \text { balls) unwashed seaweed, } \\
\text { dried at } 80^{\circ} \mathrm{C} \text { for } 24 \mathrm{~h}\end{array}$ & \multirow[b]{2}{*}{ 1:1.33 in $400 \mathrm{~mL}$; WWT } & \multirow{2}{*}{$\begin{array}{l}\text { Bottle sealed with adaptor } \\
\text { attached to gas measuring device } \\
\text { (GMD), } 38^{\circ} \mathrm{C}, 25 \text { days, } \\
\text { manually shaken }\end{array}$} & $1 \mathrm{~mm}: 241$ & -26.5 & - & - & \multirow[b]{2}{*}{95} \\
\hline & $\begin{array}{l}\text { Particle size: } 1-2 \mathrm{~mm} \text {. } \\
\text { Control: cut, unwashed. }\end{array}$ & & & 2mm: 260 & -20.7 & - & - & \\
\hline \multirow{3}{*}{$\begin{array}{l}\text { F. vesiculosus } \\
\text { (Autumn 2014) }\end{array}$} & $\begin{array}{c}\text { Frozen until treatment } \\
\end{array}$ & \multirow{3}{*}{ 5:1 in $60 \mathrm{~mL}$; WWT } & \multirow{3}{*}{$\begin{array}{l}\text { Serum bottles, gas measured with } \\
\text { syringe, } 37^{\circ} \mathrm{C}, 30 \text { days. }\end{array}$} & $W+C: 81.1$ & +574.3 & $25^{1}$ & - & \multirow{3}{*}{ [23] } \\
\hline & $\begin{array}{l}\text { Test: Washing (W) and chopped (C) }(<5 \mathrm{~mm}) \text {; unwashed } \\
\text { (UW) and chopped; washed and not chopped (NC). }\end{array}$ & & & $U W+C: 67.3$ & +493.6 & $21^{1}$ & - & \\
\hline & Control: not washed or chopped & & & $W+N C: 73.1$ & +527.5 & $23^{1}$ & - & \\
\hline
\end{tabular}


Table 3. Cont

\begin{tabular}{|c|c|c|c|c|c|c|c|c|}
\hline Algae (Harvest Time) & Pre-treatment & I/S Ratio; Source & BMP Method & $\mathrm{CH}_{4}$ Yield (mL g $\left.{ }^{-1} \mathrm{VS}\right)$ & $\%$ Change & BI (\%) & $\Delta \mathrm{BI}(\%)$ & Ref. \\
\hline \multicolumn{9}{|c|}{ Beating } \\
\hline $\begin{array}{l}\text { Laminaria spp. } \\
\text { (November 2013) }\end{array}$ & $\begin{array}{l}\text { Test: Cut without washing and beaten (Hollander beater), } \\
76 \text { mm gap, } 10 \mathrm{~min} \text { (min). } \\
\text { Control: only cut, unwashed. }\end{array}$ & 1:1.33 in $400 \mathrm{~mL}$; WWT & $\begin{array}{l}\text { Bottle with adaptor attached to } \\
\text { GMD, } 38^{\circ} \mathrm{C}, 25 \text { days, } \\
\text { shaken manually }\end{array}$ & 335 & +2.1 & - & - & [95] \\
\hline $\begin{array}{l}\text { Laminaria spp. } \\
\text { (May 2014) } \\
\text { A. nodosum } \\
\text { (August 2014) }\end{array}$ & $\begin{array}{l}\text { Test: Cut without washing and beaten (Hollander beater), } \\
76 \text { m gap, } 15 \text { min. } \\
\text { Control: only cut, unwashed. }\end{array}$ & $\begin{array}{l}\text { 1.2:1 (Laminaria spp.), 3:1 } \\
\text { (A. nodosum) in } 400 \mathrm{~mL} \text {; WWT }\end{array}$ & $\begin{array}{l}\text { Bottle attached to GMD, } 38^{\circ} \mathrm{C} \\
14 \text { days, shaken manually }\end{array}$ & $\begin{array}{l}240 \\
169\end{array}$ & $\begin{array}{l}+8.6 \\
+30\end{array}$ & - & - & [96] \\
\hline \multicolumn{9}{|c|}{ Washing } \\
\hline $\begin{array}{l}\text { U. lactuca } \\
\text { (June 2011) }\end{array}$ & $\begin{array}{l}\text { Test: Washed and dried (room temperature) }(24 \mathrm{~h}) . \\
\text { Control: Unwashed } \\
\text { Both frozen }\left(-20^{\circ} \mathrm{C}\right) \text {, grinded: } 10-15 \mathrm{~mm} .\end{array}$ & $\begin{array}{l}\text { 3:1 in } 400 \mathrm{~mL} \text {; reactor using grass, } \\
\text { dairy slurry and seaweed. }\end{array}$ & $\begin{array}{l}\text { Bioprocess AMPTS II system, } \\
37^{\circ} \mathrm{C}, 30 \text { days. }\end{array}$ & 221 & +33.9 & $55^{1}$ & $+53.2^{1}$ & [97] \\
\hline $\begin{array}{l}\text { U. lactuca } \\
\text { (April) }\end{array}$ & $\begin{array}{l}\text { Test: Washed } 2 \%(w / v) \text { seaweed in water, } 24 \mathrm{~h}, \\
\text { chopped }(2 \times 2 \mathrm{~cm})(\mathrm{C}) \text { or macerated }(\mathrm{M}) . \\
\text { Control: Unwashed }(\mathrm{C} \text { or M) }\end{array}$ & $\begin{array}{l}\text { 8:1 in } 500 \mathrm{~mL} \text {; reactor using } \\
\text { cattle manure. }\end{array}$ & $\begin{array}{l}\text { Bottles with rubber stoppers, } \\
\text { aluminium crimp, } 52^{\circ} \mathrm{C}, 42 \text { days. }\end{array}$ & $\begin{array}{l}W+C: 171 \\
W+M: 200\end{array}$ & $\begin{array}{l}-1.7 \\
-26.2\end{array}$ & - & - & [98] \\
\hline $\begin{array}{l}\text { L. digitata } \\
\text { (July 2009) }\end{array}$ & $\begin{array}{l}\text { Milled to }<1 \mathrm{~mm} \text { particle size. } \\
\text { Test: Freshwater washed }(\mathrm{W}), \text { oven dried }\left(70^{\circ} \mathrm{C}, 72 \mathrm{~h}\right)(\mathrm{OD}) \\
\text { or frozen }\left(-20^{\circ} \mathrm{C}\right) \text { and OD (FOD). } \\
\text { Control: Unwashed, OD or FOD. }\end{array}$ & 6:1 in $500 \mathrm{~mL}$; Unknown & $\begin{array}{c}\text { Bottle with rubber stoppers, } \\
\text { aluminium caps, shaken, } \\
35^{\circ} \mathrm{C}, 35 \text { days. } \\
\end{array}$ & $\begin{array}{l}W+O D: 202.9 \\
W+F O D: 248.1\end{array}$ & $\begin{array}{l}-13.8 \\
+29.4\end{array}$ & - & - & [91] \\
\hline $\begin{array}{l}\text { S. muticum } \\
\text { (June 2017) }\end{array}$ & $\begin{array}{c}\text { Test: Freshwater washed } \\
\text { Control: unwashed } \\
\text { Both frozen }\left(-20^{\circ} \mathrm{C}\right) \text {, then blended. }\end{array}$ & 9:1 in $400 \mathrm{~mL}$; paper WWT & $\begin{array}{l}\text { Automated CJC system, } \\
37^{\circ} \mathrm{C}, 28 \text { days. }\end{array}$ & 177 & -21.3 & $48^{1,2}$ & $-21.3^{1,2}$ & [79] \\
\hline $\begin{array}{l}\text { L. digitata } \\
\text { (March (M) } \\
\text { and September (S)) }\end{array}$ & $\begin{array}{l}\text { Test: Washed in cold water }(\mathrm{CO})\left(15^{\circ} \mathrm{C}\right) \text {; } \\
\text { hot water ( }(\mathrm{H})\left(40^{\circ} \mathrm{C}\right), 3 \mathrm{~min}, \mathrm{cut}(4 \mathrm{~cm}) \\
\text { Control: unwashed, cut to } 4 \mathrm{~cm} .\end{array}$ & $\begin{array}{l}\text { 2:1 in } 400 \mathrm{~mL} \text {; reactor using grass, } \\
\text { dairy slurry and seaweed. }\end{array}$ & $\begin{array}{l}\text { Bioprocess AMPTS II system, } \\
37^{\circ} \mathrm{C}, 30 \text { days. }\end{array}$ & $\begin{array}{l}\text { M,CO: } 258 \\
M, H: 283 \\
\text { S,CO: } 303 \\
\text { S,H: } 326\end{array}$ & $\begin{array}{r}+5.3 \\
+15.5 \\
+8.2 \\
+16.4 \\
\end{array}$ & $\begin{array}{l}59 \\
60 \\
67 \\
76\end{array}$ & $\begin{array}{l}+13.4 \\
+15.4 \\
+8.0 \\
+22.6\end{array}$ & [88] \\
\hline \multicolumn{9}{|c|}{ Sonication } \\
\hline $\begin{array}{c}\text { U. rigida } \\
\text { (July-September 2013) }\end{array}$ & $\begin{array}{l}\text { Test: } 30 \mathrm{~mL} \text { blended seaweed }(80 \%(w / v) \text { in water), } \\
\text { sonicated ( } 5 \mathrm{~min}, 40 \mathrm{kHz}, 120 \mathrm{~W}) \\
\text { Control: } 80 \% \text { w } w / v \text {, (assumed) blended }\end{array}$ & 1:1 in $500 \mathrm{~mL}$; Unknown & $\begin{array}{l}\text { Bottles with rubber stoppers, } \\
\text { gas measured by syringe plunger, } \\
37^{\circ} \mathrm{C} 48 \text { days. }\end{array}$ & - & +10.2 & $57^{3}$ & $+6.6^{3}$ & [99] \\
\hline
\end{tabular}

${ }^{1}$ based on Buswell equation; ${ }^{2}$ calculated based on elemental analysis provided (using Buswell equation $\left.[100,101]\right) ;{ }^{3}$ presumably based on theoretical methane yields per gram of chemical oxygen demand (COD). 


\subsubsection{Size Reduction}

Chopping or milling of the biomass is commonly used to increase the surface area to volume ratio, in order to improve the hydrolysis of complex carbohydrates to sugars for fermentation or $A D$ (Figure 1A,B) [16,102]. However, the same milling techniques used for lignocellulosic terrestrial plants may not elicit the expected increase in surface area for seaweed [83]: milling of L. digitata, which has flat blades, did not significantly increase its surface area [103].

Mechanical wet milling of L. digitata using cutting discs did not enhance glucose release [103]. Similarly, Amamou et al. (2018) [92] found that neither vibro-ball milling nor centrifugal milling of Ulva lactuca affected its sugar release. Centrifugal milling of $U$. lactuca showed a $4.4 \%$ reduction in ethanol yield. However, the same treatment on Gelidium sesquipedale showed up to a $129 \%$ increase in sugars released, increasing the ethanol yield by $80 \%$ compared to only cutting milled seaweed (Table 2). Regardless, U. lactuca still showed higher ethanol yields than G. sesquipedale, indicating that $U$. lactuca required less processing as it only required a cutting mill. Ball milling of Chaetomorha linum also enhanced bioethanol production by $63.6 \%$ compared to non-milled biomass (Table 2) [89].

The differences in the cell wall ultrastructure of seaweed can determine the beneficial value of mechanical treatment, where those with more fibrous cell walls would benefit from size reduction [94]. Experimental results by Nielsen and Heiske (2011) [94] showed that chopped or macerated samples of different seaweed species could have different effects on methane production (Table 3). Oliveira, Alves and Costa (2014) [93] found an increase of $8-16 \%$ in specific methane production after maceration of G. vermiculophylla, whilst Tedesco, Mac Lochlainn, and Olabi (2014) [104] also found an increase in methane yields with decreased particle size of Laminaria spp. On the other hand, Montingelli et al. (2016) [95] found reduced methane yields after milling of Laminaria spp., which they attributed to the inhibitory effect of volatile fatty acid (VFA) accumulation and the subsequent $\mathrm{pH}$ drop in the acidogenesis phase (Figure 1A) due to higher hydrolysis rates aided by higher surface areas [95,104]. It has been proposed that a mixture of smaller and larger particle sizes would be beneficial for increasing methane yields during $\mathrm{AD}$ [104].

\subsubsection{Beating}

Apart from size reduction by the cutting action, beating also involves pounding the seaweed against a plate, enabling the production of seaweed pulp at different consistencies depending on the machine setting [95]. A Hollander beater has been investigated by a number of researchers [86,95,96,104,105]. A comparison between beating, milling and microwave pre-treatments of Laminaria spp. found that beating was the most effective pre-treatment to enhance methane production from seaweed [95], and more effective than drying before ball milling in terms of net energy gain.

Montingelli et al. (2016) and Montingelli et al. (2017) [95,96] reported only marginal increases in methane yields from beaten seaweed compared to those that were only cut (Table 3), but rates of degradation were improved. Furthermore, although higher methane yields were obtained from the beating of Laminaria spp. collected in November compared to collection in May (Table 3), similar conclusions on faster hydrolysis rates were drawn [95]. On the other hand, beating of A. nodosum at low VS concentrations also enhanced methane yields, but an increase in hydrolysis rate was not observed [96].

\subsubsection{Washing}

Washing in freshwater is a pre-treatment step often used in a wide variety of seaweed biofuel research studies (See also Section 3.2 above) [30,34,42,106-112]. Washing has been used to remove inert impurities, such as gravel and sand, limiting their build-up in reactors [98]. Washing also removes salts which can be inhibitory at high concentrations to both methane production and enzymatic hydrolysis for bioethanol production [89,113]. Chisti (2013) [114], in a review of the constraints to the 
commercialisation of algal fuels, suggested that seaweed should be washed in fresh water to reduce the salt content.

Adams, Schmidt, and Gallagher (2015) [91] found that higher ethanol yields were obtained from unwashed samples compared to washed samples of L. digitata (Table 2), attributed to the loss of water-soluble carbohydrates such as fermentable laminarin and glucose [91].

Mixed effects of washing seaweed on methane production have been found for different species (Table 3). Washed and macerated $U$. lactuca had around $26 \%$ lower methane yields than the unwashed and macerated [98], but 34\% higher methane yields when washed and wilted (dried at room temperature) compared to unwashed and wilted [97], with an increase in BI of 53\%. A $42 \%$ increase in methane production was found for G. vermiculophylla when washed and macerated compared to the unwashed and macerated [93]. Washed and cut L. digitata was also found to have higher methane yields compared to unwashed and cut [88]. Furthermore, even though Table 3 indicates a negative impact on methane yields after washing of S. muticum, statistical analysis showed that washing did not affect yields [79]. Loss of readily digested substrates or removal of hydrolytic bacteria from seaweed surfaces were suggested to slow down the initial rate of methane production [79], indicating that initial stages of AD could be affected (Figure $1 \mathrm{~A})$.

Hot water washing $\left(40^{\circ} \mathrm{C}\right)$ of L. digitata increased VS content by up to $31 \%$, due to the removal of ash and nitrogenous compounds, compared to cold water washing $\left(15^{\circ} \mathrm{C}\right)$ and unwashed [88]. The lower ash to VS ratio for hot water washing, proposed to contribute to higher methane yields [88], do not seem to correlate with the changes in methane content for other washing experiments. Low ash to VS ratio was observed in A. nodosum, but the lower methane content was attributed to polyphenols [38]. Furthermore, washing may also reduce vital trace elements such as cobalt and selenium that have a considerable effect on AD [115]. Hence, the change in the mineral content of the seaweed after washing may also be a contributory factor in the lack of correlation between methane production and lower ash to VS ratio following washing.

In summary, if washing is found to have insignificant roles in biofuel yields, the removal of a washing process could greatly benefit industrial downstream seaweed processes for biofuel production, saving large quantities of water. However, salt accumulation in continuously-stirred digesters can cause further problems to the microbial community [38] and, therefore, industrial-scale digesters may need to be salt-acclimated if unwashed seaweed is to be used (see also Section 4.5.1).

\subsection{Thermal Treatment}

Thermal pre-treatment is able to release sugars and extract polysaccharides from seaweed. The treatment of the brown seaweed, Nizimuddinia zanardini, at $121{ }^{\circ} \mathrm{C}$ released up to $84 \%$ of components such as hemicelluloses and mannitol [116], and resulted in a $22 \%$ higher methane production compared to untreated seaweed (Table 4) [116]. Autoclave treatment of the red and green seaweed, Gelidium amansii and C. linum, also increased bioethanol yields when compared to non-heat treated biomass (Table 5) $[89,117]$. The increase in bioethanol yields was correlated with an increase in exposed fibres and eroded surfaces of the seaweed, enabling higher enzymatic degradation.

However, certain structures of the seaweed such as the cortex of the seaweed were not affected by autoclave treatment, indicating the importance of the structural make-up of seaweed and the appropriate pre-treatment method required to hydrolyse these components effectively. The following section discusses different thermal pre-treatments of seaweed. 
Table 4. Methane yields following thermal pre-treatment of seaweed.

\begin{tabular}{|c|c|c|c|c|c|c|}
\hline Algae (Harvest Time) & Treatment & I/S Ratio; Source & BMP Method & $\begin{array}{c}\mathrm{CH}_{4} \text { Yield } \\
\left(\mathrm{mL} \mathrm{g}^{-1} \mathrm{VS}\right)\end{array}$ & $\%$ Change & Ref. \\
\hline $\begin{array}{c}\text { Ulva spp. } \\
\text { (Korea, Spring 2014) }\end{array}$ & $\begin{array}{c}\text { Freshwater rinsed, blended into slurry } \\
\text { Thermal: no chemical, } 90^{\circ} \mathrm{C} \\
\mathrm{HCl}: 0.1 \mathrm{M}, 90^{\circ} \mathrm{C} \\
\mathrm{NaOH}: 0.1 \mathrm{M}, 90^{\circ} \mathrm{C} \\
\text { All magnetically stirred (10 mins), oven }(6 \mathrm{~h}), \\
\text { shaken } 1 \text { min every half hour. } \\
\text { Control: untreated slurry }\end{array}$ & $\begin{array}{l}\text { unknown ( } 35 \mathrm{~mL} \text { slurry and } 70 \mathrm{~mL} \\
\text { inoculum); sewage sludge digester }\end{array}$ & $\begin{array}{l}\text { Bottles with rubber stopper and } \\
\text { aluminium cap, } 35^{\circ} \mathrm{C}, 30 \text { days. } \\
\text { Shaken manually intermittently. }\end{array}$ & $\begin{array}{c}\text { Thermal: } 293.0 \\
0.1 \mathrm{M} \mathrm{HCl}: 284.8 \\
0.1 \mathrm{M} \mathrm{NaOH}: 251.3\end{array}$ & $\begin{array}{l}+15.8 \\
+12.7 \\
-0.7\end{array}$ & [118] \\
\hline $\begin{array}{l}\text { S. latissima } \\
\text { (August 2010) }\end{array}$ & $\begin{array}{l}\text { Defrosted, shredded into slurry. } \\
\text { Test: steam exploded } 130^{\circ} \mathrm{C} \text { or } 160^{\circ} \mathrm{C}, 10 \text { mins. } \\
\text { Control: untreated slurry }\end{array}$ & 7:1 in $700 \mathrm{~g}$; sewage treatment plant. & $\begin{array}{l}\text { Bottles with rubber stopper, aluminium } \\
\text { screw caps, shaker }\left(90 \mathrm{rpm}, 37^{\circ} \mathrm{C}\right) \\
\text { Re-fed day } 67 \text {, biogas shown: day } 119 .\end{array}$ & $\begin{array}{l}130^{\circ} \mathrm{C}: 268 \\
160^{\circ} \mathrm{C}: 260\end{array}$ & $\begin{array}{l}+20.2 \\
+16.6\end{array}$ & [119] \\
\hline $\begin{array}{l}\text { N. zanardini } \\
\text { (July) }\end{array}$ & $\begin{array}{c}\text { Washed, dried }\left(40{ }^{\circ} \mathrm{C}, 24 \mathrm{~h}\right) \text {; hammer milled to }<1 \mathrm{~mm} \text {. } \\
\text { Test: } 5 \% \text { seaweed, } 121^{\circ} \mathrm{C}, 0.5 \mathrm{~h} . \\
\text { Control: untreated. }\end{array}$ & unknown; WWT & $\begin{array}{l}\text { Bottles closed with rubber stopper, } \\
\text { aluminium caps, } 37^{\circ} \mathrm{C}, 40 \text { days. }\end{array}$ & 143 & +22 & [116] \\
\hline $\begin{array}{l}\text { Laminaria spp. } \\
\text { (November 2013) }\end{array}$ & $\begin{array}{c}\text { Test: Cut seaweed, Freshwater immersed, microwaved } \\
\text { (560 W) till water boiled, held for } 30 \mathrm{~s} . \\
\text { Control: cut unwashed seaweed. }\end{array}$ & 1:1.33 in $400 \mathrm{~mL}$; WWT & $\begin{array}{l}\text { Bottles sealed with adaptor attached to } \\
\text { GMD, } 38^{\circ} \mathrm{C}, 25 \text { days, shaken daily. }\end{array}$ & 244 & -25.6 & [95] \\
\hline $\begin{array}{l}\text { F. vesiculosus } \\
\text { (October 2014) }\end{array}$ & $\begin{array}{l}\text { Cut and grounded (mortar and pestle) } \\
\text { Test: microwaved (700 W), } 3 \text { mins } \\
\text { Control: not microwaved }\end{array}$ & 1:3; WWT & $\begin{array}{l}\text { Bottles with rubber stopper and metal } \\
\text { cap, } 37^{\circ} \mathrm{C}, 22 \text { days. Shaken daily. }\end{array}$ & 146.9 & +92.3 & [120] \\
\hline
\end{tabular}

Table 5. Ethanol yields following thermal pre-treatment methods.

\begin{tabular}{|c|c|c|c|c|c|c|c|}
\hline Algae (Harvest Time) & Treatment & Fermentation & $\begin{array}{l}\text { Ethanol Yield } \\
\left(\mathrm{mg} \mathrm{g}^{-1} \mathrm{DW}\right)\end{array}$ & $\%$ change & BI $^{1}(\%)$ & $\Delta \mathrm{BI}^{1}(\%)$ & Ref \\
\hline \multirow{4}{*}{$\begin{array}{l}\text { C. linum } \\
\text { (July 2009) }\end{array}$} & \multirow{4}{*}{$\begin{array}{c}\text { Washed, dried }\left(40^{\circ} \mathrm{C}\right) \text { and milled. } \\
\text { Thermal: } 4 \%(w / v) \text { seaweed, autoclaved }\left(200^{\circ} \mathrm{C}\right), 10 \text { mins, } 1 \text { bar. } \\
\text { Wet oxidation }(W O) \text { : same as thermal, } 12 \text { bars } \mathrm{O}_{2} \\
\text { Steam explosion: } 1.2 \mathrm{~kg}(35 \% \mathrm{DW}, 1.9 \mathrm{MPa}), 200^{\circ} \mathrm{C}, 5 \text { mins. } \\
\text { Plasma assisted: } 2.5 \mathrm{~g}, 1 \% \mathrm{O}_{3}, 1 \mathrm{~h} . \\
\text { Control: untreated biomass }\end{array}$} & \multirow{4}{*}{$\begin{array}{l}\text { SSF: } 10 \% \text { pre-treated seaweed } \\
\text { pre-hydrolysed, inoculated with cellulase } \\
\text { enzymes and S. cerevisiae }\left(32^{\circ} \mathrm{C} 200 \mathrm{~h}\right) .\end{array}$} & Thermal: 150 & +36.4 & 68.4 & +25.7 & \multirow{4}{*}{89} \\
\hline & & & WO: 170 & +54.5 & 77.2 & +41.9 & \\
\hline & & & Steam: 130 & +18.2 & 66.7 & +22.6 & \\
\hline & & & Plasma: 150 & +36.4 & 71.9 & +32.2 & \\
\hline
\end{tabular}

${ }^{1} \mathrm{BI}$ based on calculation from theoretical yield presented in literature (glucan theoretical yield). 


\subsubsection{Microwave}

Microwave pre-treatment appears suitable for seaweeds due to its high moisture content which facilitates a quick rise in temperature and pressure inside the cells, allowing cell wall rupturing [121,122], and enabling an increase in surface area for subsequent bioethanol or biogas production processes (Figure 1A,B). The mechanisms and the use of microwave pre-treatment of biomass for bioenergy production were reviewed by Kostas, Beneroso, and Robinson (2017) [123].

Microwave pre-treatment has mostly been used in the extraction of high-value products and polysaccharides, such as agar, carrageenan, and fucoidan from seaweed [121,124-127]. When microwave thermal treatment and a more conventional thermal treatment were compared using Undaria pinnatifida, the microwave treatment was not only more effective at extracting the polysaccharide, fucoidan, but it also degraded it to lower molecular weight compounds [128]. Subsequently, higher bioethanol or methane yields could be achieved, provided suitable microorganisms capable of utilising the compounds are available.

Another advantage is its rapid heating time that could stabilise and minimise sugar degradation at high temperatures, resulting in lower concentrations of inhibitory product, such as furfural compounds (5-hydroxymethyl furfural and furfural), formic acid, and levulinic acid, often formed during conventional inductive heating [116,129-131]. Microwave treatment of A. nodosum (150 ${ }^{\circ} \mathrm{C}$, $0.4 \mathrm{M}$ sulphuric acid $\left.\left(\mathrm{H}_{2} \mathrm{SO}_{4}\right), 1 \mathrm{~min}\right)$ showed no furfural production, and 5-hydroxymethyl furfural production was as low as $0.01 \mathrm{~g} \mathrm{~L}^{-1}$ [132]. Likewise, microwave-assisted acid hydrolysis of a red seaweed, Eucheuma denticulatum, also produced only $0.24 \mathrm{~g} \mathrm{~L}^{-1} 5$-hydroxymethyl furfural at $150{ }^{\circ} \mathrm{C}$, $0.1 \mathrm{M} \mathrm{H}_{2} \mathrm{SO}_{4}$ [133].

Furfural compounds lower ethanol yields by inhibiting cell growth of yeasts and enzymes during glycolysis (Figure 1B) [134,135]. Ethanol yields were enhanced during microwave treatment of A. nodosum, with ethanol production up to $60.7 \%$ of the theoretical yield [132]. Microwave pre-treatment of F. vesiculosus also increased methane production by $92 \%$ compared to the untreated seaweed [120]. This is a $10 \%$ enhancement in BI compared to washing and chopping of F. vesiculosus, which had similar harvesting time and BMP measurement method. However, microwave pre-treatment was unsuitable for Laminaria spp. where it was held at boiling point for $30 \mathrm{~s}$ [95]. This was found to lower methane yields by $27 \%$ compared to untreated seaweed (only cut). Its current small-scale application (20-50 mL in volume) and low ethanol concentration obtained $(0.7 \%(v / v))$ also calls for further investigations and optimisations $[132,136]$.

\subsubsection{Steam Explosion}

Steam explosion, widely used as a lignocellulosic pre-treatment process, has not been highly investigated as a thermal pre-treatment method for seaweed, possibly because the latter is considered to be much less recalcitrant. Steam explosion involves both thermal and mechanical means to hydrolyse the seaweed. Steam explosion of S. latissima for $10 \mathrm{~min}$ at $130{ }^{\circ} \mathrm{C}$ and $160{ }^{\circ} \mathrm{C}$ both showed an increase in methane production compared to untreated seaweed (Table 4) [119].

In another experiment comparing five different pre-treatment methods for C. linum (Table 5), steam-exploded seaweed at $200{ }^{\circ} \mathrm{C}$ for $5 \mathrm{~min}$ produced around $18 \%$ higher ethanol yields than untreated seaweed [89]. However, the yield of ethanol was lower than other pre-treatments tested (wet oxidation, autoclave, and plasma-assisted), which was attributed to the loss of glucans from biomass solids [89]. The fermentation was carried out on the solid fraction of the pre-treated biomass as the slurry was pressed to remove half of the liquid, with loss of $31 \%$ DW. It would, therefore, be of interest to understand bioethanol yields from the liquid and solid fraction to determine the effectiveness of steam explosion of seaweed on bioethanol production. Its high energy costs will also need to be compensated by significantly higher biofuel yields and, therefore, may not be an appropriate technology for seaweed. 


\subsubsection{Other Thermal Pre-Treatment Methods}

Other thermal pre-treatment methods include wet oxidation and plasma-assisted pre-treatment. Only one author had used these methods for the pre-treatment of seaweed (Table 5). Plasma-assisted pre-treatment involves the generation of ozone in the reactor which is thought to react and degrade unsaturated organic compounds within the biomass [137]. Ozone has also been found to reduce polyphenol concentrations [138]. Unlike steam explosion, there was no loss of dry matter after pre-treatment, a small loss in glucan, xylan, and arabinan, and no production of 5-hydroxymethyl furfural or furfural [89]. Even though the combined levels of glucan, xylan, and arabinan in the pre-treated biomass was lower than untreated biomass, the pre-treatment may have allowed higher enzymatic hydrolysis of the remaining biomass and, subsequently, higher ethanol production than untreated seaweed.

Wet oxidation was also an effective method in increasing the glucan content of the pre-treated biomass compared to the untreated seaweed [89]. Interestingly, wet oxidation resulted in the high production of formic acid and acetic acid, but its ethanol yield was $54 \%$ more than untreated biomass, and only $0.01 \mathrm{~g} \mathrm{~g}^{-1} \mathrm{DW}$ lower than the ball milled pre-treated sample. However, the direct comparison between the two would not be completely accurate as the seaweeds were harvested in different seasons.

\subsection{Chemical Treatment}

Enhancements in hydrolysis and solubilisation of seaweed during acid and alkali pre-treatments make them highly investigated methods prior to fermentation or AD [139]. Other chemicals, such as ionic liquids, 'organosolv' (a solvent-based pre-treatment), and sodium chlorite, have also been investigated as pre-treatment methods for seaweed $[140,141]$. Chemical properties play an important role in the hydrolysis of seaweed's polysaccharides. Jmel et al. (2018) [140] highlighted that the viscosity of 1-ethyl-3-methylimidazolium acetate (an ionic liquid) limited its hydrolysis potential as its access into the internal matrix was prevented by the inability to pass through the carbohydrate cell wall matrix. An in-depth investigation of the degradation of $U$. rigida by ionic liquids has been achieved by Pezoa-Conte et al. (2015) [142]. High solubilisation of seaweed and the subsequent high concentrations of reducing sugars have been achieved as a result of using different chemicals and thermochemical methods $[99,139,143]$.

\subsubsection{Alkali or Acidic Treatment}

The addition of alkalis, often sodium hydroxide $(\mathrm{NaOH})$, was proposed to cause swelling of fibres and increase pore sizes, enabling the release of sugars from within cell walls, which facilitates efficient subsequent enzymatic hydrolysis or subsequent fermentation [144]. For acidic pre-treatment, $\mathrm{H}_{2} \mathrm{SO}_{4}$, hydrochloric acid $(\mathrm{HCl})$, and flue gas condensates with low $\mathrm{pH}$ values have been investigated (Table 6). Acids are thought to hydrolyse cellulose, hemicellulose, and other storage carbohydrates such as laminarin $[139,145]$. More concentrated acid solutions are more effective at hydrolysing seaweed's cell walls to release its cell contents [145]. However, using acids has been criticised: as a hazard risk (especially concentrated acid), for incurring high acid recycling costs, and for acid-resistant process equipment requirements [145].

The benefits of increased solubility of seaweed on biogas yields appeared quite limited after pre-treatment with $\mathrm{NaOH}$ or $\mathrm{HCl}$ (Table 6). Pre-treatment of F. vesiculosus with $0.2 \mathrm{M} \mathrm{HCl}\left(80^{\circ} \mathrm{C}, 12 \mathrm{~h}\right)$ enhanced methane yield by almost 2.5 times compared to untreated seaweed and was 1.6 times higher than hydrothermal treatment $\left(80^{\circ} \mathrm{C}, 24 \mathrm{~h}\right)$ [146]. Comparatively, a similar treatment of Ulva spp. with $0.1 \mathrm{M}$ or $0.2 \mathrm{M} \mathrm{HCl}$ or $\mathrm{NaOH}$ at $60^{\circ} \mathrm{C}, 75^{\circ} \mathrm{C}$, and $90{ }^{\circ} \mathrm{C}$ did not increase methane yields compared to only thermal pre-treatment (Table 4) [118]. However, both experiments used different methods for BMP determination, making the direct comparison between the two experiments challenging. Notably, concentrations of furfural compounds present after thermo-chemical treatment of lignocellulosic biomass were not inhibitory to AD of cellulose [134], suggesting that thermo-chemical hydrolysis of seaweed could be useful in increasing biogas yields if the appropriate seaweed species is chosen. 
Table 6. Methane yields following thermochemical pre-treatment of seaweed.

\begin{tabular}{|c|c|c|c|c|c|c|}
\hline Algae (Harvest Time) & Pre-treatment & I/S Ratio; Source & BMP Method & $\begin{array}{l}\mathrm{CH}_{4} \text { Yield } \\
\left(\mathrm{mL} \mathrm{g}^{-1} \mathrm{VS}\right)\end{array}$ & $\%$ Change & Ref. \\
\hline $\begin{array}{l}\text { G. vermiculophylla } \\
\text { (March 2012) }\end{array}$ & $\begin{array}{c}\text { Algae washed, macerated } \\
\text { Test: } 0.1,0.3,0.5 \mathrm{~g} \mathrm{NaOH} \mathrm{g}{ }^{-1} \text { seaweed } \\
\left(20^{\circ} \mathrm{C}, 55^{\circ} \mathrm{C}, 90^{\circ} \mathrm{C}, 1 \text { bar, } 3.5 \text { bar, } 6 \text { bar, } 60 \text { and } 90 \text { mins }\right) \\
\text { Control: Untreated }\end{array}$ & 4:1; brewery WWT & $\begin{array}{l}\text { Glass vials with rubber stopper and } \\
\text { aluminium crimp, } 37^{\circ} \mathrm{C}, 24 \text { days }\end{array}$ & $353-380$ & -21 to -26.6 & [93] \\
\hline \multirow{3}{*}{$\begin{array}{l}\text { P. palmata } \\
\text { (March 2010) }\end{array}$} & \multirow{3}{*}{$\begin{array}{l}\text { Dried }\left(40^{\circ} \mathrm{C}\right) \text {, chopped }(2 \times 2 \mathrm{~cm}) \\
\text { Test: } 0.04 \mathrm{~g} \mathrm{NaOH} \mathrm{g} \mathrm{g}^{-1} \mathrm{TS}\left(50 \mathrm{~g} \mathrm{~L} \mathrm{~L}^{-1}\right): 20-70^{\circ} \mathrm{C}, 24 \mathrm{~h} ; \\
160^{\circ} \mathrm{C}, 0.5 \mathrm{~h} .0 .02 \mathrm{~g} \mathrm{HCl} \mathrm{g}^{-1} \mathrm{TS}, 160^{\circ} \mathrm{C}, 0.5 \mathrm{~h} . \\
\text { Control: untreated }\end{array}$} & \multirow{3}{*}{ 2:1 in $400 \mathrm{~mL}$; sugar WWT } & \multirow{3}{*}{$\begin{array}{l}\text { Glass vials with rubber stopper and } \\
\text { aluminium crimp, } 35^{\circ} \mathrm{C}, 60 \text { days. }\end{array}$} & $20-70^{\circ} \mathrm{C}: 362-365$ & +17.5 to 18.5 & \multirow{3}{*}{ [147] } \\
\hline & & & & $160^{\circ} \mathrm{C} \mathrm{NaOH}: 282$ & -8.4 & \\
\hline & & & & $160^{\circ} \mathrm{C} \mathrm{HCl}: 268$ & -13 & \\
\hline $\begin{array}{c}\text { Seaweed mixture: } \\
\text { Spermothamnion family } \\
(80-90 \%) \text {, Chaetophorales family } \\
(5-15 \%) \text {, eelgrass (2-5\%) } \\
\text { (August, 2011) }\end{array}$ & $\begin{array}{c}\text { Dried }\left(54^{\circ} \mathrm{C}\right) \text {, shredded } \\
\text { Test: Only } \mathrm{H}_{2} \mathrm{O} \text {; flue gas condensate }(\mathrm{FGC})(\mathrm{pH} 1.2) ; \\
0.05 \mathrm{M} \mathrm{HCl}\left(80^{\circ} \mathrm{C}, 2 \mathrm{~h}\right) ; 0.2 \mathrm{M} \mathrm{HCl}\left(80^{\circ} \mathrm{C}, 1.5 \mathrm{~h}\right) \\
\text { Control: Untreated }\end{array}$ & $\begin{array}{l}\text { 2:1 in } 2 \mathrm{~L} ; \text { Mixture: WWT, maize silage and } \\
\text { cattle manure, seaweed adapted sludge. }\end{array}$ & $\begin{array}{l}\text { Fermenter tanks with } \mathrm{CO}_{2} \text { absorbing } \\
\text { unit, gas drying unit, and gas volume } \\
\text { sensor, } 37^{\circ} \mathrm{C}, 22 \text { days. }\end{array}$ & $\begin{array}{c}\mathrm{H}_{2} \mathrm{O}: 80 \\
F G \mathrm{C}: 108 \\
0.05 \mathrm{M} \mathrm{HCl}: 66 \\
0.2 \mathrm{M} \mathrm{HCl}: 121\end{array}$ & $\begin{array}{l}-8.0 \\
+24.1 \\
-24.1 \\
+39.1\end{array}$ & [148] \\
\hline $\begin{array}{l}\text { Ulva spp. } \\
\text { (March 2015) }\end{array}$ & $\begin{array}{c}\text { Washed, sun dried }(1-2 \text { weeks }) \\
\text { Test: } 0.04 \mathrm{~g} \mathrm{NaOH} \mathrm{g}^{-1} \mathrm{TS}\left(20^{\circ} \mathrm{C}, 24 \mathrm{~h}\right) ; \\
0.04 \mathrm{~g} \mathrm{HCl} \mathrm{g}^{-1} \mathrm{TS}^{\circ}\left(150^{\circ} \mathrm{C}, 0.5 \mathrm{~h}\right) \\
\text { Control: untreated }\end{array}$ & 2:1 in $400 \mathrm{~mL}$; sugar wastewater industry & $\begin{array}{l}\text { Glass vials with rubber stopper, } \\
\text { aluminium crimp, } \\
35^{\circ} \mathrm{C} \text { until no gas production. }\end{array}$ & $\begin{array}{l}\mathrm{NaOH}: 148 \\
\mathrm{HCl}: 77\end{array}$ & $\begin{array}{l}+12.1 \\
-41.7\end{array}$ & {$[144$} \\
\hline $\begin{array}{l}\text { Ulva spp. } \\
\text { (Spring 2014) }\end{array}$ & $\begin{array}{l}\text { Fresh water rinsed, blended to slurry. } \\
\text { Test: } 500 \mathrm{~mL} \text { slurry, no chemical; } 0.01 \mathrm{M} \mathrm{HCl} ; 0.1 \mathrm{M} \mathrm{NaOH} \text {. } \\
\text { All } 90^{\circ} \mathrm{C}, 6 \mathrm{~h} \text {, manual shaking every } 0.5 \mathrm{~h}, 1 \mathrm{~min} \text {. } \\
\text { Control: untreated }\end{array}$ & Sewage sludge digester & $\begin{array}{l}\text { Bottles with rubber stopper, } \\
\text { aluminium cap, } 35^{\circ} \mathrm{C}, 30 \text { days, } \\
\text { shaken manually intermittently. }\end{array}$ & $\begin{array}{l}\text { Only thermal: } 293.0 \\
0.1 \mathrm{M} \mathrm{HCl:} 284.8 \\
0.1 \mathrm{M} \mathrm{NaOH}: 251.3\end{array}$ & $\begin{array}{l}+15.8 \\
+12.7 \\
-0.7\end{array}$ & [118 \\
\hline $\begin{array}{c}\text { L. digitata } \\
\text { (Unknown time) }\end{array}$ & $\begin{array}{c}\text { Fresh Water rinsed, dried }\left(75^{\circ} \mathrm{C}, 24 \mathrm{~h}\right) \text {, milled. } \\
\text { Test: } 20 \% \text { solids loading, } 2.5 \% \text { citric acid }(\mathrm{CA}) ; 6 \% \text { citric acid; } \\
1 \% \text { lactic acid (LA), autoclaved }\left(120{ }^{\circ} \mathrm{C}, 1 \mathrm{~h}, 1 \mathrm{~atm}\right) \\
\text { Control: untreated }\end{array}$ & $\begin{array}{l}\text { 2:1 in } 30 \mathrm{~mL} \text {; } \\
\text { bovine slurry adapted to seaweed. }\end{array}$ & $\begin{array}{l}\text { Serum bottles ( } \mathrm{pH} \text { 7.3-7.5) with rubber } \\
\text { stopper and aluminium crimp, } \\
\qquad 35^{\circ} \mathrm{C}, 32 \text { days. }\end{array}$ & $\begin{array}{c}2.5 \% C A: 237 \\
6 \% C A: 69 \\
\text { LA: } 161\end{array}$ & $\begin{array}{l}+3.9 \\
-69.7 \\
-29.4\end{array}$ & [53] \\
\hline $\begin{array}{l}\text { F. vesiculosus } \\
\text { (Unknown time) }\end{array}$ & $\begin{array}{c}\text { Dried, crushed, homogenised } \\
\text { Test: } 0.2 \mathrm{M} \mathrm{HCl}\left(800^{\circ} \mathrm{C}, 12 \mathrm{~h}\right) ; \mathrm{FGC}\left(\mathrm{pH} 2.2,0.13 \mathrm{M}, 80^{\circ} \mathrm{C}, 24 \mathrm{~h}\right) \\
\text { Control: untreated }\end{array}$ & $\begin{array}{l}\text { 2:1 in } 2 \mathrm{~L} \text {; mixture: WWT, corn silage, } \\
\text { seaweed adapted sludge. }\end{array}$ & $\begin{array}{l}\text { Fermenter tanks, } \mathrm{CO}_{2} \text { absorbing unit } \\
\text { and gas volume sensor, } 37^{\circ} \mathrm{C}, 20 \text { days. }\end{array}$ & $\begin{array}{l}\text { HCl: } 116 \\
\text { FGC: } 65\end{array}$ & $\begin{array}{l}+147 \\
+38.3\end{array}$ & [146] \\
\hline
\end{tabular}


Production of furfural compounds is, however, a major issue when using acid pre-treatment for bioethanol production [149]. When 20 seaweed species collected from the same geographical location were subject to the same pre-treatment $\left(0.2 \mathrm{M} \mathrm{H}_{2} \mathrm{SO}_{4}, 121^{\circ} \mathrm{C}, 15 \mathrm{~min}\right)$, different ethanol yields and different concentrations of 5-hydroxymethyl furfural were obtained [149]. High concentrations of 5-hydroxymethyl furfural appears to be related to low ethanol yields even though high levels of galactose for fermentation are seen (Figure 3). The removal of 5-hydroxymethyl furfural by activated charcoal can successfully increase ethanol yields per gram of galactose present [129]. Interestingly, 5-hydroxymethyl furfural concentrations decreased during fermentation of G. amansii, suggesting the metabolism of these compounds by the yeasts [129]. Use of these compounds as a carbon source by aerobic bacteria has also been discussed by Monlau et al. (2014) [134].

Some successes have been achieved for bioethanol production using thermo-chemical pre-treatment methods [150]. The species-dependent effect of thermochemical pre-treatment, with differential effects on solubilisation of seaweed and subsequent biofuel yields [145], appear to be associated with differences in the biochemical composition of the seaweed. For example, fucoidan and alginate were depolymerised at different temperatures [151,152] and, therefore, the proportion of these components in each macroalgal type could affect the extent of seaweed hydrolysis under the same conditions.

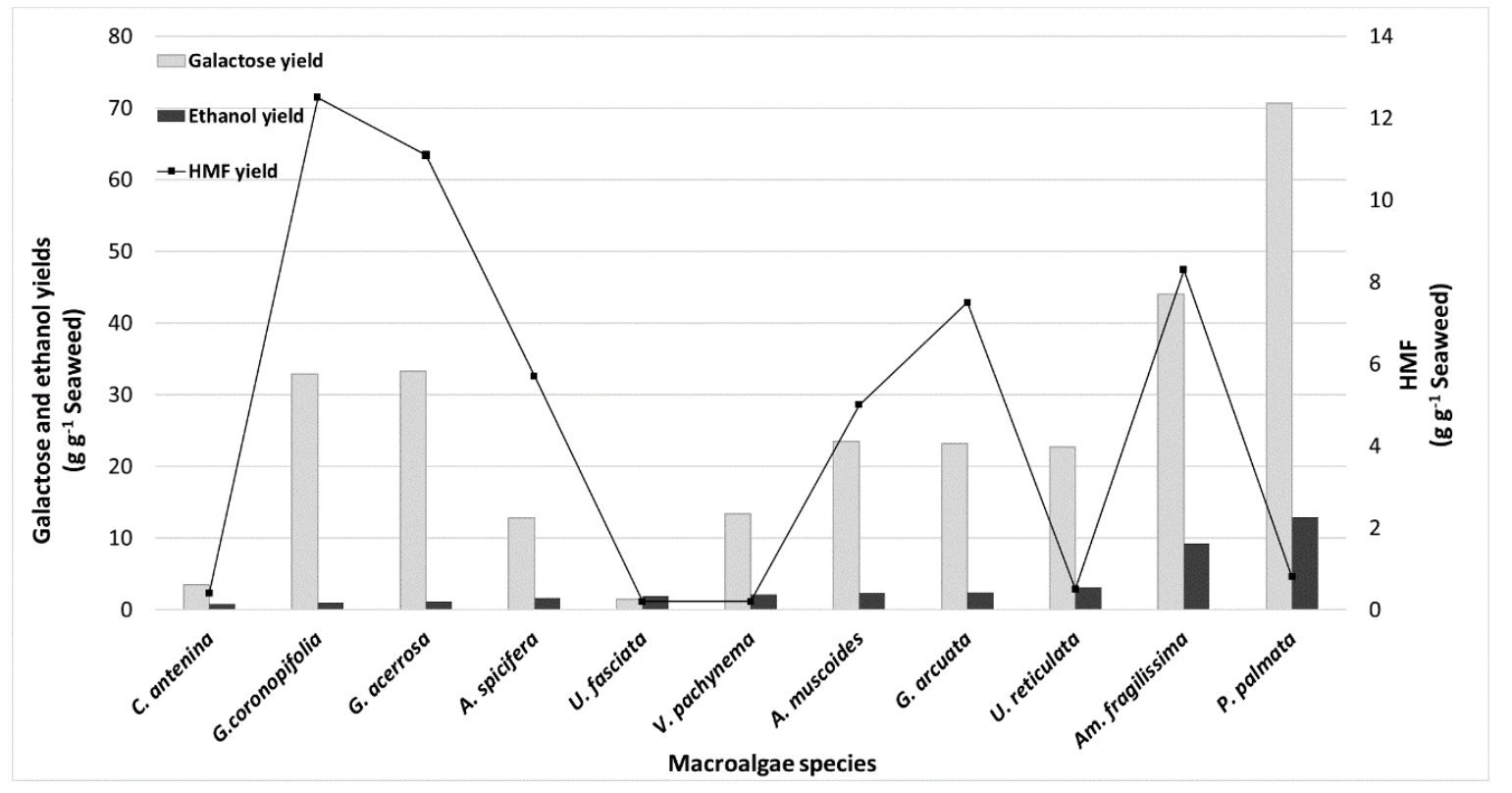

Figure 3. Galactose, 5-hydroxymethyl furfural (HMF), and ethanol yields from different seaweed species using data from Mutripah et al. (2014) [135].

High salt content in seaweeds, including calcium, sodium, magnesium, and potassium salts, can also negatively impact ethanol yields by increasing salinity levels during fermentation [145]. Salinity can also be enhanced by the use of acid and alkali treatments of seaweed [118,145] and, therefore, this pre-treatment method may not be appropriate for seaweeds with high salt contents if high biofuel yields were to be achieved (see also Section 4.5.1).

Additionally, seaweeds adsorbing different concentrations of heavy metals could be differentially solubilised by acid hydrolysis, where the presence of aluminium and iron ions in microalgae affected optimal concentrations of sulphuric acid required for optimal reducing sugar yields [153]. Based on response surface methodology (RMS), for the same seaweed substrate, different experimental conditions (reaction temperature, acid concentration, and reaction time) affects the amounts of 5-hydroxymethyl furfural, glucose, and galactose formed [154].

The difficulty in identifying the appropriate pre-treatment to yield the least inhibitory by-product and high biofuel yields suggest that an approach carried out by Dandikas et al. (2014) [155] and 
Dandikas et al. (2018) [156] may be useful for seaweed. This involves performing a primary component analysis of numerous different species of seaweed harvested during different times of year, and locations, and identifying the correlation of different components to biofuel yields. Not only would this help to identify the appropriate pre-treatment method for different seaweed, but also identify the characteristics of suitable seaweeds that can be mass-cultivated for biofuel production.

\subsubsection{Peroxide Treatment}

This pre-treatment method uses thermal treatment to enhance the disruption of seaweed crystalline structures and hydrogen bonds by hydroxyl radicals [157]. A higher cellulose to glucose conversion rate of $88.1 \%$ has been achieved using this treatment compared to alkali and acid pre-treatments of seaweed [32,157], after hot water pre-treatment $\left(100{ }^{\circ} \mathrm{C}, 30 \mathrm{~min}\right)$ followed by a hydroxyl radical reaction step $\left(0.018 \% \mathrm{H}_{2} \mathrm{O}_{2}\right.$ and $\left.11.9 \mathrm{mM} \mathrm{FeSO}_{4}\right)$ [32]. Additionally, hydroxyl radical pre-treatment of 4 different species of seaweed all showed an increase in glucose yield per gram dry matter compared to untreated seaweed, indicating an increase in enzymatic digestibility [157]. The risk of producing inhibitory furfurals is also reduced with peroxide treatment and polysaccharides, such as laminarin and alginates, remained intact with this pre-treatment $[157,158]$.

\subsection{Biological Treatment}

Biological pre-treatment involves the use of enzymes or the direct use of microorganisms for the degradation of seaweed. Recently, Perez et al. (2018) [159] studied the capabilities of laminarinase and cellulase in saccharifying Sargassum spp. Commercial enzymes such as Celluclast 1.5L, Novozym, and other cellulase preparations, or a mix of enzymes for enzymatic saccharification after acid hydrolysis, have also been used [30,150,160,161].

For AD purposes, direct addition of suitable microorganisms able to degrade the complex polysaccharides within seaweeds is more effective than use of enzymes for improving biogas yields (Table 7) [99,162]. Decomposed seaweed collected from the beach also produced higher biogas yields compared to fresh seaweed [163]. Unwashed Ulva spp. digested using seaweed-adapted slurry containing seawater, mud, and sand showed higher methane yields and a higher biodegradability of $36 \%$ compared to washed seaweed digested with seaweed-adapted slurry, initially fed food waste (Table 7). Treatment of Laminaria japonica using Vibrio harveyi and Vibrio alginolyticus, capable of producing alginate lyase to break down alginates, also yielded higher amounts of VFAs available for biogas production compared to alkali pre-treatment [164].

$V$. harveryi can also grow on cellobiose [164], which may have enabled the increase in VFA compared to untreated seaweed during the pre-treatment of red and green seaweed by $V$. harvery $i$ and V. alginolyticus [165]. Multiple mechanisms of biological pre-treatment have also been discovered using Aspergillus fumigatus to degrade Ulva spp. via solid-state fermentation [144]. Methane yield enhancements were also observed when treating a mixture of seaweed from the Mexican Caribbean using Trametes hirsuta, known to enzymatically degrade lignocellulosics [166].

There are also continuous isolations of new enzymes and microorganisms capable of increasing hydrolysis of seaweed's complex polysaccharides [167,168]. Microbes isolated from sheep fed with seaweed could degrade the seaweed's polysaccharides, but methane yields were higher from individual polysaccharides than the total biomass even though similar levels of acetate (a component of VFA) were produced [169]. This could be due to polyphenols present within seaweed (see Section 4.5.2) [170,171]. 
Table 7. Methane yield following biological pre-treatment of seaweed.

\begin{tabular}{|c|c|c|c|c|c|c|c|c|}
\hline Algae (Harvest Time) & Pre-treatment & Inoculum & BMP Method & $\begin{array}{l}\mathrm{CH}_{4} \text { Yield } \\
\left(\mathrm{ml} \mathrm{g}^{-1} \mathrm{VS}\right)\end{array}$ & $\%$ Change & BI (\%) & $\Delta \mathrm{BI}(\%)$ & Ref. \\
\hline $\begin{array}{c}\text { Ulva rigida } \\
\text { (July-September 2013) }\end{array}$ & $\begin{array}{l}\text { Test: } 7.5 \mathrm{~mL} \text { A. niger filtrate to } 50 \mathrm{~mL} \text { blended seaweed } \\
\left(80 \%(w / v) \text { in water), } 50^{\circ} \mathrm{C}, 100 \mathrm{rpm}, 2 \mathrm{~h} .\right. \\
\text { Repeated with } \beta \text {-glucosidase. } \\
\text { Control: untreated seaweed. }\end{array}$ & $\begin{array}{l}\text { I/S ratio: } 1: 1 \text { in } 500 \mathrm{~mL} \\
\text { Source: (unknown) } \\
\text { treatment plant. }\end{array}$ & $\begin{array}{l}\text { Bottles with rubber stoppers, } 37^{\circ} \mathrm{C} \text {. } \\
\text { Gas measured using syringe plunger. }\end{array}$ & - & $\begin{array}{l}\text { A. niger: }+33^{1} \\
\beta \text {-glu.: }+28^{1}\end{array}$ & $\begin{array}{l}63^{2} \\
58^{2}\end{array}$ & $\begin{array}{r}+17.1^{2} \\
+7.8^{2}\end{array}$ & [99] \\
\hline $\begin{array}{l}\text { Ulva spp. } \\
\text { (March 2015) }\end{array}$ & $\begin{array}{c}\text { Test: washed, sun dried (1-2 weeks), grounded. } 35 \% \\
\text { seaweed in Mandels' salt solution, autoclaved }\left(120^{\circ} \mathrm{C} \text {, }\right. \\
20 \text { mins); inoculated: } A \text {. fumigatus SL1 conidia suspension; } \\
\text { incubated (50 }{ }^{\circ} \mathrm{C} \text {, eight days). } \\
\text { Control: untreated. }\end{array}$ & $\begin{array}{l}\mathrm{I} / \mathrm{S} \text { ratio: } 2: 1 \mathrm{in} 400 \mathrm{~mL} \text { with buffer } \\
\text { and nutrients } \\
\text { Source: sugar wastewater industry. }\end{array}$ & $\begin{array}{l}\text { Vials with rubber stopper and } \\
\text { aluminium crimp, } 35^{\circ} \mathrm{C} \text { till gas } \\
\text { production halts. }\end{array}$ & 153 & +15.9 & $57^{3}$ & $+16.3^{3}$ & [144] \\
\hline $\begin{array}{l}\text { Ulva spp. } \\
\text { (June 2013) }\end{array}$ & $\begin{array}{l}\text { Test: } 100 \mathrm{~g} \text { washed or unwashed seaweed } \\
\text { (macerated }<5 \mathrm{~mm} \text { ) in } 100 \mathrm{~g} \text { freshwater or thalassic } \\
\text { hydrolytic inoculum; } 3 \text { days, } 37^{\circ} \mathrm{C} \text {. } \\
\text { Control: untreated with hydrolytic inoculum }\end{array}$ & $\begin{array}{l}\text { Source: Freshwater: washed } \\
\text { seaweed-adapted, original slurry: } \\
\text { food waste. } \\
\text { Thalassic: Unwashed } \\
\text { seaweed-adapted, original slurry: } \\
\text { seawater, mud, sand }\end{array}$ & $\begin{array}{l}100 \mathrm{~g} \text { of respective methanogenic } \\
\text { inoculum, } 37^{\circ} \mathrm{C}, 6 \text { days. }\end{array}$ & $\begin{array}{l}77.7 \\
180.9\end{array}$ & $\begin{array}{c}\text { Freshwater: }+42.8 \\
\text { Thalassic: }+72\end{array}$ & $\begin{array}{l}27 \\
63\end{array}$ & $\begin{array}{l}+42.4^{3} \\
+71.8^{3}\end{array}$ & [172] \\
\hline $\begin{array}{l}\text { L. digitata } \\
\text { (unknown time) }\end{array}$ & $\begin{array}{c}\text { Freshwater rinsed, dried }\left(75^{\circ} \mathrm{C}, 24 \mathrm{~h}\right) \text {, milled. } 20 \%(w / v) \\
\text { seaweed in water with: } \\
\text { Cellulase }(\mathrm{C}): 37^{\circ} \mathrm{C} ; \\
\text { Alginate lyase }(\mathrm{AL}): 37^{\circ} \mathrm{C} ; \\
\text { or Celluclast }{ }^{\otimes} 1.5 \mathrm{~L}(\mathrm{C} 1.5): 40^{\circ} \mathrm{C} \text {. } \\
\text { All incubated: } 300 \mathrm{rpm}, 24 \mathrm{~h} \\
\text { Control: water (room temp., } 24 \mathrm{~h})\end{array}$ & $\begin{array}{l}\mathrm{I} / \mathrm{S} \text { ratio: } 2: 1 \mathrm{in} 30 \mathrm{~mL} \text { (pH 7.3-7.5) } \\
\text { Source: bovine slurry } \\
\text { (seaweed-adapted). }\end{array}$ & $\begin{array}{l}\text { Bottles with rubber stopper and } \\
\text { aluminium crimp, } 35^{\circ} \mathrm{C}, 32 \text { days. }\end{array}$ & $\begin{array}{l}\text { C: } 232 \\
\text { AL: } 225 \\
\text { C1.5: } 72\end{array}$ & $\begin{array}{l}+1.8 \\
-1.3 \\
-68.4\end{array}$ & $\begin{array}{l}- \\
-\end{array}$ & $\begin{array}{l}- \\
-\end{array}$ & [53] \\
\hline
\end{tabular}

${ }^{1}$ BI calculated from theoretical methane yields based on per gram COD; ${ }^{2}$ based on biogas yields; ${ }^{3} \mathrm{BI}$ calculated from theoretical yields based on crude protein, lipids and carbohydrates. 


\subsection{Inhibitor Removal}

As discussed in previous sections, there is a range of inhibitors, such as phenolics and salts, implicated in limiting production yields of both ethanol during fermentation and methane during AD. The removal of these inhibitors as part of the pre-treatment process before fermentation and AD may not only improve biofuel yields, but also obtain potential high-value by-products. The following sections further discusses the role of these inhibitors and the possible removal methods of these compounds.

\subsubsection{Salts}

Although low salt concentrations can stimulate microbial growth, high salt concentrations $\left(\geq 10 \mathrm{~g} \mathrm{~L}^{-1}\right)$ inhibit the methanogenesis phase of $\mathrm{AD}$ (Figure 1A) through an increase of osmotic pressure or dehydration of methanogenic microorganisms $[37,173]$. The sodium cation predominantly determines the toxicity of salt but other light metal ions, such as potassium, are also toxic to methanogens at high levels [174]. An optimal sodium concentration for mesophilic methanogens in waste treatment processes of $230 \mathrm{mg} \mathrm{Na} \mathrm{L}^{-1}$ has been recommended [175]. However, the approximate level of sodium found in seawater is $14 \mathrm{~g} \mathrm{Na} \mathrm{L}^{-1}$, and at this level, mesophilic methanogenic activity is halved [175-177].

Anaerobic digesters can be acclimatised to higher salt levels if they are continuously exposed to gradually increasing salt concentration by adaptation of methanogens rather than salt shock $[173,178]$. After acclimation, the sodium concentration to halve methanogenic activity can increase to $37.4 \mathrm{~g} \mathrm{Na} \mathrm{L}^{-1}$ [175]. Thalassic conditions are capable of producing higher methane yields when digesting unwashed seaweed compared to freshwater conditions digesting washed seaweed (Table 7). It, therefore, appears possible to produce biogas from seaweed without fresh water washing, which increases production costs. Otherwise, the high salt concentration could also be mitigated by mixing the seaweed biomass with other types of biomass to 'dilute' the salt [13].

\subsubsection{Phenolics}

Phenols are a diverse group of polymerisation products of phloroglucinol (1,3,5-trihydroxybenzene), widely distributed in plants and algae with $>8000$ phenolic compounds being separated from terrestrial and marine organisms [179,180]. High levels of phenolics are found in many seaweeds, with brown seaweed containing up to $14 \% \mathrm{DW}$ [181]. The phenolic compounds in cell wall structures are generally considered to be used as a chemical defence mechanism against grazers, bacteria, fungi, and other epiphytes [72,182].

Low molecular weight phlorotannins, ranging from $126 \mathrm{kDa}$ to $650 \mathrm{kDa}$ [183], damage microbial cells by altering membrane permeability, including those of gram-negative bacteria [184], causing leakage of intracellular components and inactivating essential enzymatic systems; with lower molecular weight phenolics being more toxic to microorganisms than high molecular weight compounds [134]. Phenolic extracts from S. muticum showed antimicrobial activity against some aerobic bacteria [185]. Hierholtzer et al. (2013) [186] highlighted the role of phlorotannins in bactericidal effects on anaerobic microorganisms found in sludge from wastewater treatment plant. Resistive microbes to the bactericidal effects were also detected, suggesting that biogas production is still possible from seaweed containing phlorotannins. Polyphenols extracted from brown seaweed also inhibited $\alpha$-amylase, $\alpha$-glucosidase, and lipase $[187,188]$, implying possible enzymatic inhibition by seaweed during the hydrolysis stages of fermentation and AD (Figure 1A,B).

The mode of action of phlorotannins, found in brown seaweed, on anaerobic microorganisms remains obscure, and there is little information available regarding their influence on mixed microbial cultures found in anaerobic digesters [186]. Concentrations of up to $7 \%$ gallic acid, epicatechin, and phloroglucinol did not inhibit the breakdown of simple and readily digestible compound, glycerol, but there were statistically significant interactions on methane yield between high levels of phenolics and complex substrates [69]. Tabassum et al. (2016) [189] found an association between the high phenolic content in A. nodosum and reduced methane yields. Moen et al. (1997) [170] found that 
the methanogenesis phase of $\mathrm{AD}$ was inhibited by polyphenols (Figure $1 \mathrm{~A}$ ), and biogas production was improved during $\mathrm{AD}$ of $A$. nodosum when polyphenols were 'fixed' by formaldehyde. Moreover, alginate degradation was suggested to be limited by the binding of polyphenols to alginates which limited the degradation by alginate lyases during $\mathrm{AD}$ [171]. It may, therefore, be beneficial to understand the concentrations of phlorotannins in a reactor during $\mathrm{AD}$ of seaweed to elucidate the magnitude of its inhibitory role.

The removal of polyphenols using formaldehyde would be too costly on a large-scale. Alternatively, there is a growing body of research showing the potential uses of polyphenols and seaweed extracts, including pharmacology and food industry use $[187,190,191]$. Thus, the removal of phlorotannins before AD or fermentation may form the basis of a useful biorefinery, yielding potentially bioactive substances at the same time as improving biofuel yield. These phenolic compounds could be extracted as part of the pre-treatment method. For example, microwave-assisted extraction has been achieved [192], and subsequent fermentation and AD could be carried out on remaining residues [193].

\subsubsection{Heavy Metals}

Seaweeds can accumulate heavy metals on cell wall polysaccharides and are able to bind and chelate to heavy metals [194]. These heavy metals include $\mathrm{Fe}, \mathrm{Pb}, \mathrm{Cd}, \mathrm{Mn}$, and $\mathrm{Cu}$ which have been measured in seaweed in the Bulgarian Black Sea [195], as well as Zn, Cr, and Hg in seaweed from the Aegean Sea [196]. Heavy metals are indicated as inhibitors of AD, provided the freely available ions exceed specific inhibitory threshold values of the particular heavy metal [197]. The potential additive inhibitory effect of different heavy metals may also lower these thresholds [197]. However, the removal of heavy metals using iminodiacetic acid (IDA) cryogel adsorbents reduced methane yields during the two-stage AD of seaweed compared to those without heavy metal removal [198]. This was suggested to be due to higher sulphate content as a consequence of heavy metal removal, resulting in an increase in $\mathrm{H}_{2} \mathrm{~S}$ and sulphates as less are precipitated off [198]. Furthermore, the concentrations of heavy metals initially present may not have exceeded threshold values to cause inhibitory effects.

Nevertheless, heavy metal removal will be required if seaweeds are to be used in a biorefinery, with digestate being used as soil conditioners or fertilisers [199]. For example, cadmium concentrations found in the digestate of a digester digesting seaweed harvested in Germany was above legal limits for fertilisers [148]. Nkemka and Murto (2012) [199] have suggested using sulphide precipitation followed by IDA-cryogel carriers to remove and possibly recover these metal ions, while others have suggested carbonate or hydroxide precipitation [197].

\subsubsection{Other}

Inhibitors forming as a result of thermal or thermo-chemical pre-treatment, including 5-hydroxymethyl furfural and furfural, have been discussed by Shobana et al. (2017) [200]. Briefly, removal of these compounds can be achieved by methods such as 'overliming' (providing calcium ions and a high $\mathrm{pH}$, often using calcium hydroxide [201]), use of ethyl acetate, or using activated carbon [200]. Otherwise, different hydrolysis reactor configurations have been found to reduce the formation of these inhibitory compounds [130]. However, the cost-effectiveness of these methods will need to be analysed for the subsequent increase in biofuel yields after detoxification.

\section{Conclusions}

Seaweed biomass has the potential to serve as a feedstock for biofuel production but is currently harvested primarily for high-value natural products and food only. A biorefinery approach to processing seaweed would open up opportunities to sustainably process the biomass into a spectrum of food and feed ingredients, bio-based chemicals, and materials, as well as biofuel, without affecting current industries. However, to fully realise the value of seaweed biomass in terms of its potential to produce biofuel, appropriate seaweed pre-treatments will be required. Green, brown, and red seaweeds differ in terms of their polysaccharide composition and contents, and the arrangement of 
these polymers in cell wall architectures. In order to maximise yields of biofuel, be it biogas from AD processing, or bioethanol from alcoholic fermentation, or both, these polysaccharides need to be hydrolysed at appropriate rates to their component sugars if they are to then serve successfully as feedstock for processing to biofuels by the corresponding microbial communities. Biofuel yields from either AD or fermentation of seaweed are also greatly dependent on seasonality of harvested seaweed and their location at the time of harvest, since these factors influence salt content, heavy metal content, polyphenols, structural make-up, and the relative content of the different polymeric carbohydrates.

This review has shown that there is a range of different methods available that will variously break down seaweed cell wall architecture, improve access to seaweed polymers for their initial hydrolysis, and remove/prevent formation of compounds, such as furanic acids and phenolics, that might be inhibitory to subsequent microbial metabolic processes. These include reducing particle size, beating, thermal and thermo-chemical methods, and biological methods, such as the addition of specific microbial inocula for $\mathrm{AD}$ processes or addition of cellulolytic enzymes for fermentation. Acid or alkali pre-treatments, whilst effective in swelling fibres and hydrolysing polymers, unfortunately increase the risk of producing inhibitory compounds and consequently amongst chemical treatments, appear less attractive than for example, the use of peroxides. Washing seaweed in freshwater is a common practice to remove inhibitory salt, but since results to date have been mixed in terms of the effects on biofuel yield, the value of this pre-treatment warrants further research to reduce impacts on sustainability. On the other hand, a major area of research need lies in devising practices that could reduce the heavy metal content in seaweeds: seaweeds accumulate these on negatively-charged polysaccharide components, and their presence not only reduces biofuel yields but requires monitoring to ensure safe practice in the management of subsequent digestate. Finally, note should be made of pre-treatments based on ensiling seaweed. Although its effect on subsequent biofuel yields is not well-developed, this practice could serve to ensure continuity in biomass supply throughout the year, as well as overcome the influence of seasonality on seaweed properties, and thereby significantly improve processing sustainability in the longer term.

In summary, with a sound understanding of the history and source of seaweed and its biomass composition and properties, it becomes possible to design suitable seaweed pre-treatments that will maximise sustainability and the EROI for biofuel production, at lowest cost.

Author Contributions: Conceptualisation: J.J.M. and B.V.N.; writing—original draft preparation: S.M. and J.J.M.; writing—review and editing: J.J.M., B.V.N., and P.J.H.; supervision: J.J.M., B.V.N., and P.J.H.

Acknowledgments: The author would like to acknowledge the financial support of the University of Greenwich and the Doctoral Training Alliance.

Conflicts of Interest: The authors declare no conflict of interest.

\section{References}

1. West, J.; Calumpong, H.P.; Martin, G. Chapter 14-Seaweeds. In The First Global Integrated Marine: Assessment World Ocean Assessment I; United Nations: Cambridge, United Kingdom, 2017; pp. 1-10.

2. Fishstat -Fishery and Aquaculture Statistics, version 3.04.9; Global Aquaculture Production 1950-2016; FAO Fisheries and Aquaculture Department: Rome, Italy, 2018.

3. Milledge, J.J.; Heaven, S. Methods of energy extraction from microalgal biomass: A review. Rev. Environ. Sci. Bio/Technol. 2014, 13, 301-320. [CrossRef]

4. Chen, H.; Qiu, T.; Rong, J.; He, C.; Wang, Q. Microalgal biofuel revisited: An informatics-based analysis of developments to date and future prospects. Appl. Energy 2015, 155, 585-598. [CrossRef]

5. Kerrison, P.D.; Stanley, M.S.; Edwards, M.D.; Black, K.D.; Hughes, A.D. The cultivation of European kelp for bioenergy: Site and species selection. Biomass Bioenergy 2015, 80, 229-242. [CrossRef]

6. Milledge, J.J.; Harvey, P.J. Potential process 'hurdles' in the use of macroalgae as feedstock for biofuel production in the British Isles. J. Chem. Technol. Biotechnol. 2016, 91, 2221-2234. [CrossRef] [PubMed]

7. Gao, K.; McKinley, K.R. Use of macroalgae for marine biomass production and $\mathrm{CO}_{2}$ remediation: A review. J. Appl. Phycol. 1994, 6, 45-60. [CrossRef] 
8. Florentinus, A.; Harmelinck, C.; de Lint, S.; van Iersel, S. Worldwide Potential of Aquatic Biomass; Ecofys: Utrecht, The Netherlands, 2014; pp. 1-66.

9. Pechsiri, J.S.; Thomas, J.-B.E.; Risén, E.; Ribeiro, M.S.; Malmström, M.E.; Nylund, G.M.; Jansson, A.; Welander, U.; Pavia, H.; Gröndahl, F. Energy performance and greenhouse gas emissions of kelp cultivation for biogas and fertilizer recovery in Sweden. Sci. Total Environ. 2016, 573, 347-355. [CrossRef] [PubMed]

10. European Commission. Available online: Https:/ / ec.europa.eu/energy/en/topics/energy-strategy-andenergy-union/2030-energy-strategy (accessed on 24 September 2018).

11. Murphy, J.D.; Drosg, B.; Allen, E.; Jerney, J.; Xia, A.; Herrmann, C. A Perspective on Algal Biogas; IEA Bioenergy: Paris, France, 2015; pp. 1-38.

12. Horn, S.J. Bioenergy from brown seaweeds. Ph.D. Thesis, Norwegian University of Science and Technology NTNU, Trondheim, Norway, November 2000.

13. Murphy, F.; Devlin, G.; Deverell, R.; McDonnell, K. Biofuel Production in Ireland-An Approach to 2020 Targets with a Focus on Algal Biomass. Energies 2013, 6, 6391-6412. [CrossRef]

14. Milledge, J.J.; Smith, B.; Dyer, P.W.; Harvey, P. Macroalgae-derived biofuel: A review of methods of energy extraction from seaweed biomass. Energies 2014, 7, 7194-7222. [CrossRef]

15. Liu, X.; Saydah, B.; Eranki, P.; Colosi, L.M.; Greg Mitchell, B.; Rhodes, J.; Clarens, A.F. Pilot-scale data provide enhanced estimates of the life cycle energy and emissions profile of algae biofuels produced via hydrothermal liquefaction. Bioresour. Technol. 2013, 148, 163-171. [CrossRef] [PubMed]

16. Wei, N.; Quarterman, J.; Jin, Y.-S.S. Marine macroalgae: An untapped resource for producing fuels and chemicals. Trends Biotechnol. 2013, 31, 70-77. [CrossRef] [PubMed]

17. Allen, E.; Wall, D.M.; Herrmann, C.; Xia, A.; Murphy, J.D. What is the gross energy yield of third generation gaseous biofuel sourced from seaweed? Energy 2015, 81, 352-360. [CrossRef]

18. Murphy, J.; Braun, R.; Weiland, P.; Wellinger, A. Biogas from Crop Digestion Task 37—Energy from Biogas; IEA Bioenergy: Paris, France, 2011; pp. 1-23.

19. Seghetta, M.; Østergård, H.; Bastianoni, S. Energy analysis of using macroalgae from eutrophic waters as a bioethanol feedstock. Ecol. Modell. 2014, 288, 25-37. [CrossRef]

20. Taelman, S.E.; Champenois, J.; Edwards, M.D.; De Meester, S.; Dewulf, J. Comparative environmental life cycle assessment of two seaweed cultivation systems in North West Europe with a focus on quantifying sea surface occupation. Algal Res. 2015, 11, 173-183. [CrossRef]

21. Alvarado-Morales, M.; Boldrin, A.; Karakashev, D.B.; Holdt, S.L.; Angelidaki, I.; Astrup, T. Life cycle assessment of biofuel production from brown seaweed in Nordic conditions. Bioresour. Technol. 2013, 129, 92-99. [CrossRef] [PubMed]

22. Aitken, D.; Bulboa, C.; Godoy-Faundez, A.; Turrion-Gomez, J.L.; Antizar-Ladislao, B. Life cycle assessment of macroalgae cultivation and processing for biofuel production. J. Clean. Prod. 2014, 75, 45-56. [CrossRef]

23. Pastare, L.; Aleksandrovs, I.; Lauka, D.; Romagnoli, F. Mechanical Pre-treatment Effect on Biological Methane Potential from Marine Macro Algae: Results from Batch Tests of Fucus Vesiculosus. Energy Procedia 2016, 95, 351-357. [CrossRef]

24. Hessami, M.J.; Phang, S.-M.; Salleh, A.; Rabiei, R. Evaluation of tropical seaweeds as feedstock for bioethanol production. Int. J. Environ. Sci. Technol. 2018, 15, 977-992. [CrossRef]

25. Marquez, G.P.; Santiañez, W.J.; Trono, G.C.; Rose, S.; de la Rama, S.R.; Takeuchi, H.; Hasegawa, T. Seaweeds: A sustainable fuel source. In Seaweed Sustainability: Food and Non-Food Applications; Tiwari, B.K., Troy, D.J., Eds.; Academic Press: Oxford, UK, 2015; pp. 421-458, ISBN 978-0-12-419958-3.

26. Adams, J.M.M.; Toop, T.A.; Donnison, I.S.; Gallagher, J.A. Seasonal variation in Laminaria digitata and its impact on biochemical conversion routes to biofuels. Bioresour. Technol. 2011, 102, 9976-9984. [CrossRef] [PubMed]

27. Borines, M.G.; de Leon, R.L.; Cuello, J.L. Bioethanol production from the macroalgae Sargassum spp. Bioresour. Technol. 2013, 138, 22-29. [CrossRef] [PubMed]

28. Golberg, A.; Vitkin, E.; Linshiz, G.; Khan, S.A.; Hillson, N.J.; Yakhini, Z.; Yarmush, M.L. Proposed design of distributed macroalgal biorefineries: Thermodynamics, bioconversion technology, and sustainability implications for developing economies. Biofuels Bioprod. Biorefining-Biofpr 2014, 8, 67-82. [CrossRef]

29. Wang, D.; Yun, E.J.; Kim, S.; Kim, D.H.; Seo, N.; An, H.J.; Kim, J.-H.; Cheong, N.Y.; Kim, K.H. Efficacy of acidic pretreatment for the saccharification and fermentation of alginate from brown macroalgae. Bioprocess Biosyst. Eng. 2016, 39, 959-966. [CrossRef] [PubMed] 
30. Yanagisawa, M.; Nakamura, K.; Ariga, O.; Nakasaki, K. Production of high concentrations of bioethanol from seaweeds that contain easily hydrolyzable polysaccharides. Process Biochem. 2011, 46, 2111-2116. [CrossRef]

31. Kawai, S.; Murata, K. Biofuel production based on carbohydrates from both brown and red macroalgae: Recent developments in key biotechnologies. Int. J. Mol. Sci. 2016, 17, 145. [CrossRef] [PubMed]

32. Gao, F.; Gao, L.; Zhang, D.; Ye, N.; Chen, S.; Li, D. Enhanced hydrolysis of Macrocystis pyrifera by integrated hydroxyl radicals and hot water pretreatment. Bioresour. Technol. 2015, 179, 490-496. [CrossRef] [PubMed]

33. Barbot, Y.N.; Thomsen, C.; Thomsen, L.; Benz, R. Anaerobic digestion of laminaria japonica waste from industrial production residues in laboratory- and pilot-scale. Mar. Drugs 2015, 13, 5947-5975. [CrossRef] [PubMed]

34. McKennedy, J.; Sherlock, O. Anaerobic digestion of marine macroalgae: A review. Renew. Sustain. Energy Rev. 2015, 52, 1781-1790. [CrossRef]

35. Habig, C.; Ryther, J.H. Methane production from the anaerobic digestion of some marine macrophytes. Resour. Conserv. 1983, 8, 271-279. [CrossRef]

36. Østgaard, K.; Indergaard, M.; Markussen, S.; Knutsen, S.H.; Jensen, A. Carbohydrate degradation and methane production during fermentation of Laminaria saccharina (Laminariales, Phaeophyceae). J. Appl. Phycol. 1993, 5, 333-342. [CrossRef]

37. Hierholtzer, A.; Akunna, J.C. Modelling sodium inhibition on the anaerobic digestion process. Water Sci. Technol. 2012, 66, 1565-1573. [CrossRef] [PubMed]

38. Tabassum, M.R.; Xia, A.; Murphy, J.D. Biomethane production from various segments of brown seaweed. Energy Convers. Manag. 2018, 174, 855-862. [CrossRef]

39. Rodriguez, C.; Alaswad, A.; Mooney, J.; Prescott, T.; Olabi, A.G. Pre-treatment techniques used for anaerobic digestion of algae. Fuel Process. Technol. 2015, 138, 765-779. [CrossRef]

40. Jung, K.A.; Lim, S.-R.R.; Kim, Y.; Park, J.M. Potentials of macroalgae as feedstocks for biorefinery. Bioresour. Technol. 2013, 135, 182-190. [CrossRef] [PubMed]

41. Michalak, I. Experimental processing of seaweeds for biofuels. Wiley Interdiscip. Rev. Energy Environ. 2018, 7, 1-25. [CrossRef]

42. Ross, A.B.; Jones, J.M.; Kubacki, M.L.; Bridgeman, T. Classification of macroalgae as fuel and its thermochemical behaviour. Bioresour. Technol. 2008, 99, 6494-6504. [CrossRef] [PubMed]

43. Díaz-Vázquez, L.M.; Rojas-Pérez, A.; Fuentes-Caraballo, M.; Robles, I.V.; Jena, U.; Das, K.C. Demineralization of Sargassum spp. Macroalgae Biomass: Selective Hydrothermal Liquefaction Process for Bio-Oil Production. Front. Energy Res. 2015, 3. [CrossRef]

44. Milledge, J.J.; Harvey, P.J. Ensilage and anaerobic digestion of Sargassum muticum. J. Appl. Phycol. 2016, 28, 3021-3030. [CrossRef]

45. Kloareg, B.; Quatrano, R.S. Structure of the cell walls of marine algae and ecophysiological functions of the matrix polysaccharides. Oceanogr. Mar. Biol. An Annu. Rev. 1988, 26, 259-315.

46. Darcy-Vrillon, B. Nutritional aspects of the developing use of marine macroalgae for the human food industry. Int. J. Food Sci. Nutr. 1993, 44, S23-S25.

47. Hurd, C.L.; Harrison, P.J.; Bischof, K.; Lobban, C.S. Seaweed Ecology and Physiology, 2nd ed.; Cambridge University Press: Cambridge, UK, 2014; ISBN 0521145953.

48. Synytsya, A.; Čopíková, J.; Kim, W.J.; Park, Y. Cell Wall Polysaccharides of Marine Algae. In Springer Handbook of Marine Biotechnology; Kim, S.K., Ed.; Springer: Berlin/Heidelberg, Germany, 2015; pp. 543-590, ISBN 978-3-642-53971-8.

49. Deniaud-Bouët, E.; Kervarec, N.; Michel, G.; Tonon, T.; Kloareg, B.; Hervé, C. Chemical and enzymatic fractionation of cell walls from Fucales: Insights into the structure of the extracellular matrix of brown algae. Ann. Bot. 2014, 114, 1203-1216. [CrossRef] [PubMed]

50. Yahmed, N.B.; Jmel, M.A.; Ben Alaya, M.; Bouallagui, H.; Marzouki, M.N.; Smaali, I. A biorefinery concept using the green macroalgae Chaetomorpha linum for the coproduction of bioethanol and biogas. Energy Convers. Manag. 2016, 119, 257-265. [CrossRef]

51. Lahaye, M.; Robic, A. Structure and function properties of Ulvan, a polysaccharide from green seaweeds. Biomacromolecules 2007, 8, 1765-1774. [CrossRef] [PubMed]

52. Bobin-Dubigeon, C.; Lahaye, M.; Guillon, F.; Barry, J.L.; Gallant, D.J. Factors limiting the biodegradation of Ulva sp. cell-wall polysaccharides. J. Sci. Food Agric. 1997, 75, 341-351. [CrossRef] 
53. Vanegas, C.H.; Hernon, A.; Bartlett, J. Enzymatic and organic acid pretreatment of seaweed: Effect on reducing sugars production and on biogas inhibition. Int. J. Ambient Energy 2015, 36, 2-7. [CrossRef]

54. McDermid, K.J.; Stuerckea, B.; Haleakala, O.J. Total dietary fiber content in Hawaiian marine algae. Bot. Mar. 2005, 48, 1-3. [CrossRef]

55. Lahaye, M. Marine Algae as Sources of Fibers: Determination of Soluble and Insoluble Dietary Fiber Contents in Some 'Sea Vegetables'. J. Sci. Food Agric. 1991, 54, 587-594. [CrossRef]

56. De Jesus Raposo, M.F.; de Morais, A.M.M.B.; de Morais, R.M.S.C. Emergent Sources of Prebiotics: Seaweeds and Microalgae. Mar. Drugs 2016, 14, 27. [CrossRef] [PubMed]

57. Gallagher, J.A.; Turner, L.B.; Adams, J.M.M.; Barrento, S.; Dyer, P.W.; Theodorou, M.K. Species variation in the effects of dewatering treatment on macroalgae. J. Appl. Phycol. 2018, 30, 2305-2316. [CrossRef] [PubMed]

58. Cabrita, A.R.J.J.; Maia, M.R.G.G.; Sousa-Pinto, I.; Fonseca, A.J.M.M. Ensilage of seaweeds from an integrated multi-trophic aquaculture system. Algal Res. Biofuels Bioprod. 2017, 24, 290-298. [CrossRef]

59. Wei, F.; Ito, K.; Sakata, K.; Date, Y.; Kikuchi, J. Pretreatment and integrated analysis of spectral data reveal seaweed similarities based on chemical diversity. Anal. Chem. 2015, 87, 2819-2826. [CrossRef] [PubMed]

60. Date, Y.; Sakata, K.; Kikuchi, J. Chemical profiling of complex biochemical mixtures from various seaweeds. Polym. J. 2012, 44, 888-894. [CrossRef]

61. Rodriguez-Jasso, R.M.; Mussatto, S.I.; Pastrana, L.; Aguilar, C.N.; Teixeira, J.A. Chemical composition and antioxidant activity of sulphated polysaccharides extracted from Fucus vesiculosus using different hydrothermal processes. Chem. Pap. 2014, 68, 203-209. [CrossRef]

62. Percival, E. The polysaccharides of green, red and brown seaweeds: Their basic structure, biosynthesis and function. Br. Phycol. J. 1979, 14, 103-117. [CrossRef]

63. Berteau, O.; Mulloy, B. Sulfated fucans, fresh perspectives: Structures, functions, and biological properties of sulfated fucans and an overview of enzymes active toward this class of polysaccharide. Glycobiology 2003, 13, 29-40. [CrossRef] [PubMed]

64. Yun, E.J.; Choi, I.-G.; Kim, K.H. Red macroalgae as a sustainable resource for bio-based products. Trends Biotechnol. 2015, 33, 247-249. [CrossRef] [PubMed]

65. Rioux, L.-E.; Turgeon, S.L.; Beaulieu, M. Characterization of polysaccharides extracted from brown seaweeds. Carbohydr. Polym. 2007, 69, 530-537. [CrossRef]

66. Jang, J.-S.; Cho, Y.; Jeong, G.-T.; Kim, S.-K. Optimization of saccharification and ethanol production by simultaneous saccharification and fermentation (SSF) from seaweed, Saccharina japonica. Bioprocess Biosyst. Eng. 2012, 35, 11-18. [CrossRef] [PubMed]

67. Alves, A.; Sousa, R.A.; Reis, R.L. A practical perspective on ulvan extracted from green algae. J. Appl. Phycol. 2013, 25, 407-424. [CrossRef]

68. Robic, A.; Gaillard, C.; Sassi, J.-F.; Lerat, Y.; Lahaye, M. Ultrastructure of ulvan: A polysaccharide from green seaweeds. Biopolymers 2009, 91, 652-664. [CrossRef] [PubMed]

69. Milledge, J.J.; Nielsen, B.V.; Harvey, P.J. The inhibition of anaerobic digestion by model phenolic compounds representative of those from Sargassum muticum. J. Appl. Phycol. 2018. [CrossRef]

70. Sharma, S.; Neves, L.; Funderud, J.; Mydland, L.T.; Øverland, M.; Horn, S.J. Seasonal and depth variations in the chemical composition of cultivated Saccharina latissima. Algal Res. 2018, 32, 107-112. [CrossRef]

71. Andrade, L.R.; Leal, R.N.; Noseda, M.; Duarte, M.E.R.; Pereira, M.S.; Mourão, P.A.S.; Farina, M.; Amado Filho, G.M. Brown algae overproduce cell wall polysaccharides as a protection mechanism against the heavy metal toxicity. Mar. Pollut. Bull. 2010, 60, 1482-1488. [CrossRef] [PubMed]

72. Plouguerne, E.; Le Lann, K.; Connan, S.; Jechoux, G.; Deslandes, E.; Stiger-Pouvreau, V. Spatial and seasonal variation in density, reproductive status, length and phenolic content of the invasive brown macroalga Sargassum muticum (Yendo) Fensholt along the coast of Western Brittany (France). Aquat. Bot. 2006, 85, 337-344. [CrossRef]

73. Philippsen, A.; Wild, P.; Rowe, A. Energy input, carbon intensity and cost for ethanol produced from farmed seaweed. Renew. Sustain. Energy Rev. 2014, 38, 609-623. [CrossRef]

74. Hurtado, A.Q.; Gerung, G.S.; Yasir, S.; Critchley, A.T. Cultivation of tropical red seaweeds in the BIMP-EAGA region. J. Appl. Phycol. 2014, 26, 707-718. [CrossRef]

75. Gallagher, J.A.; Turner, L.B.; Adams, J.M.M.; Dyer, P.W.; Theodorou, M.K. Dewatering treatments to increase dry matter content of the brown seaweed, kelp (Laminaria digitata ((Hudson) JV Lamouroux)). Bioresour. Technol. 2017, 224, 662-669. [CrossRef] [PubMed] 
76. Herrmann, C.; Fitzgerald, J.; O'shea, R.; Xia, A.; O'kiely, P.; Murphy, J.D.; O'Shea, R.; Xia, A.; O'Kiely, P.; Murphy, J.D. Ensiling of seaweed for a seaweed biofuel industry. Bioresour. Technol. 2015, 196, 301-313. [CrossRef] [PubMed]

77. Sandbakken, I.S.; Sæther, M.; Funderud, J.; Aasen, I.M. Acid preservation of Saccharina latissima for application as a carbon source for fermentation to biofuels and chemicals. J. Appl. Phycol. 2018, 1-8. [CrossRef]

78. Redden, H.; Milledge, J.J.; Greenwell, H.C.; Dyer, P.W.; Harvey, P.J. Changes in higher heating value and ash content of seaweed during ensiling. J. Appl. Phycol. 2017, 29, 1037-1046. [CrossRef]

79. Milledge, J.J.; Nielsen, B.V.; Sadek, M.S.; Harvey, P.J. Effect of Freshwater Washing Pretreatment on Sargassum muticum as a Feedstock for Biogas Production. Energies 2018, 11, 1771. [CrossRef]

80. Charmley, E.; Savoie, P.; McRae, K.B.; Lu, X. Effect of maceration at mowing on silage conservation, voluntary intake, digestibility and growth rate of steers fed precision chopped or round bale silages. Can. J. Anim. Sci. 1999, 79, 195-202. [CrossRef]

81. Muller, C.E. Long-stemmed vs. cut haylage in bales-Effects on fermentation, aerobic storage stability, equine eating behaviour and characteristics of equine faeces. Anim. Feed Sci. Technol. 2009, 152, 307-321. [CrossRef]

82. Driehuis, F.; van Wikselaar, P.G. The occurrence and prevention of ethanol fermentation in high-dry-matter grass silage. J. Sci. Food Agric. 2000, 80, 711-718. [CrossRef]

83. Adams, J.M.M.; Bleathman, G.; Thomas, D.; Gallagher, J.A. The effect of mechanical pre-processing and different drying methodologies on bioethanol production using the brown macroalga Laminaria digitata (Hudson) JV Lamouroux. J. Appl. Phycol. 2017, 29, 2463-2469. [CrossRef]

84. Raposo, F.; Fernández-Cegrí, V.; de la Rubia, M.A.; Borja, R.; Béline, F.; Cavinato, C.; Demirer, G.; Fernández, B.; Fernández-Polanco, M.; Frigon, J.C.; et al. Biochemical methane potential (BMP) of solid organic substrates: Evaluation of anaerobic biodegradability using data from an international interlaboratory study. J. Chem. Technol. Biotechnol. 2011, 86, 1088-1098. [CrossRef]

85. Vanegas, C.H.; Bartlett, J. Green energy from marine algae: Biogas production and composition from the anaerobic digestion of Irish seaweed species. Environ. Technol. 2013, 34, 2277-2283. [CrossRef] [PubMed]

86. Tedesco, S.; Marrero Barroso, T.; Olabi, A.G. Optimization of mechanical pre-treatment of Laminariaceae spp. biomass-derived biogas. Renew. Energy 2014, 62, 527-534. [CrossRef]

87. Hughes, A.D.; Kelly, M.S.; Black, K.D.; Stanley, M.S. Biogas from Macroalgae: Is it time to revisit the idea? Biotechnol. Biofuels 2012, 5, 1-7. [CrossRef] [PubMed]

88. Tabassum, M.R.; Xia, A.; Murphy, J.D. Comparison of pre-treatments to reduce salinity and enhance biomethane yields of Laminaria digitata harvested in different seasons. Energy 2017, 140, 546-551. [CrossRef]

89. Schultz-Jensen, N.; Thygesen, A.; Leipold, F.; Thomsen, S.T.; Roslander, C.; Lilholt, H.; Bjerre, A.B. Pretreatment of the macroalgae Chaetomorpha linum for the production of bioethanol-Comparison of five pretreatment technologies. Bioresour. Technol. 2013, 140, 36-42. [CrossRef] [PubMed]

90. Korzen, L.; Pulidindi, I.N.; Israel, A.; Abelson, A.; Gedanken, A. Single step production of bioethanol from the seaweed Ulva rigida using sonication. RSC Adv. 2015, 5, 16223-16229. [CrossRef]

91. Adams, J.M.M.; Schmidt, A.; Gallagher, J.A. The impact of sample preparation of the macroalgae Laminaria digitata on the production of the biofuels bioethanol and biomethane. J. Appl. Phycol. 2015, 27, 985-991. [CrossRef]

92. Amamou, S.; Sambusiti, C.; Monlau, F.; Dubreucq, E.; Barakat, A. Mechano-enzymatic deconstruction with a new enzymatic cocktail to enhance enzymatic hydrolysis and bioethanol fermentation of two macroalgae species. Molecules 2018, 23, 174. [CrossRef] [PubMed]

93. Oliveira, J.V.; Alves, M.M.; Costa, J.C. Design of experiments to assess pre-treatment and co-digestion strategies that optimize biogas production from macroalgae Gracilaria vermiculophylla. Bioresour. Technol. 2014, 162, 323-330. [CrossRef] [PubMed]

94. Nielsen, H.B.; Heiske, S. Anaerobic digestion of macroalgae: Methane potentials, pre-treatment, inhibition and co-digestion. Water Sci. Technol. 2011, 64, 1723-1729. [CrossRef] [PubMed]

95. Montingelli, M.E.; Benyounis, K.Y.; Stokes, J.; Olabi, A.G. Pretreatment of macroalgal biomass for biogas production. Energy Convers. Manag. 2016, 108, 202-209. [CrossRef]

96. Montingelli, M.E.; Benyounis, K.Y.; Quilty, B.; Stokes, J.; Olabi, A.G. Influence of mechanical pretreatment and organic concentration of Irish brown seaweed for methane production. Energy 2017, 118, 1079-1089. [CrossRef]

97. Allen, E.; Browne, J.; Hynes, S.; Murphy, J.D. The potential of algae blooms to produce renewable gaseous fuel. Waste Manag. 2013, 33, 2425-2433. [CrossRef] [PubMed] 
98. Bruhn, A.; Dahl, J.; Nielsen, H.B.; Nikolaisen, L.; Rasmussen, M.B.; Markager, S.; Olesen, B.; Arias, C.; Jensen, P.D. Bioenergy potential of Ulva lactuca: Biomass yield, methane production and combustion. Bioresour. Technol. 2011, 102, 2595-2604. [CrossRef] [PubMed]

99. Karray, R.; Hamza, M.; Sayadi, S. Evaluation of ultrasonic, acid, thermo-alkaline and enzymatic pre-treatments on anaerobic digestion of Ulva rigida for biogas production. Bioresour. Technol. 2015, 187, 205-213. [CrossRef] [PubMed]

100. Symons, G.E.; Buswell, A.M. The Methane Fermentation of Carbohydrates ${ }^{1,2}$. J. Am. Chem. Soc. 1933, 55, 2028-2036. [CrossRef]

101. Buswell, A.M.; Mueller, H.F. Mechanism of Methane Fermentation. Ind. Eng. Chem. 1952, 44, 550-552. [CrossRef]

102. Tsapekos, P.; Kougias, P.G.; Angelidaki, I. Biogas production from ensiled meadow grass; effect of mechanical pretreatments and rapid determination of substrate biodegradability via physicochemical methods. Bioresour. Technol. 2015, 182, 329-335. [CrossRef] [PubMed]

103. Manns, D.; Andersen, S.K.; Saake, B.; Meyer, A.S. Brown seaweed processing: Enzymatic saccharification of Laminaria digitata requires no pre-treatment. J. Appl. Microbiol. 2016, 28, 1287-1294. [CrossRef]

104. Tedesco, S.; Mac Lochlainn, D.; Olabi, A.G. Particle size reduction optimization of Laminaria spp. biomass for enhanced methane production. Energy 2014, 76, 857-862. [CrossRef]

105. Rodriguez, C.; El-Hassan, Z.; Olabi, A.G.; Alaswad, A. Optimization of the anaerobic digestion process of mechanically pretreated algae. In 11th Conference on Sustainable Development of Energy, Water and Environment Systems, SDEWES; Faculty of Mechanical Engineering and Naval Architecture: Zagreb, Croatia, 2016; pp. $1-12$.

106. Wang, X.; Liu, X.; Wang, G. Two-stage hydrolysis of invasive algal feedstock for ethanol fermentation. J. Integr. Plant Biol. 2011, 53, 246-252. [CrossRef] [PubMed]

107. González-López, N.; Moure, A.; Domínguez, H.; Gonzalez-Lopez, N.; Moure, A.; Dominguez, H. Hydrothermal fractionation of Sargassum muticum biomass. J. Appl. Phycol. 2012, 24, 1569-1578. [CrossRef]

108. Choi, J.; Choi, J.W.; Suh, D.J.; Ha, J.M.; Hwang, J.W.; Jung, H.W.; Lee, K.Y.; Woo, H.C. Production of brown algae pyrolysis oils for liquid biofuels depending on the chemical pretreatment methods. Energy Convers. Manag. 2014, 86, 371-378. [CrossRef]

109. Suutari, M.; Leskinen, E.; Fagerstedt, K.; Kuparinen, J.; Kuuppo, P.; Blomster, J. Macroalgae in biofuel production. Phycol. Res. 2015, 63, 1-18. [CrossRef]

110. Kumar, S.; Gupta, R.; Kumar, G.; Sahoo, D.; Kuhad, R.C. Bioethanol production from Gracilaria verrucosa, a red alga, in a biorefinery approach. Bioresour. Technol. 2013, 135, 150-156. [CrossRef] [PubMed]

111. Park, J.H.; Yoon, J.J.; Park, H.D.; Lim, D.J.; Kim, S.H. Anaerobic digestibility of algal bioethanol residue. Bioresour. Technol. 2012, 113, 78-82. [CrossRef] [PubMed]

112. Tabassum, M.R.; Xia, A.; Murphy, J.D. The effect of seasonal variation on biomethane production from seaweed and on application as a gaseous transport biofuel. Bioresour. Technol. 2016, 209, 213-219. [CrossRef] [PubMed]

113. Zhang, Y.; Alam, M.A.; Kong, X.; Wang, Z.; Li, L.; Sun, Y.; Yuan, Z. Effect of salinity on the microbial community and performance on anaerobic digestion of marine macroalgae. J. Chem. Technol. Biotechnol. 2017, 92, 2392-2399. [CrossRef]

114. Chisti, Y. Constraints to commercialization of algal fuels. J. Biotechnol. 2013, 167, 201-214. [CrossRef] [PubMed]

115. Banks, C.J.; Zhang, Y.; Jiang, Y.; Heaven, S. Trace element requirements for stable food waste digestion at elevated ammonia concentrations. Bioresour. Technol. 2012, 104, 127-135. [CrossRef] [PubMed]

116. Yazdani, P.; Zamani, A.; Karimi, K.; Taherzadeh, M.J. Characterization of Nizimuddinia zanardini macroalgae biomass composition and its potential for biofuel production. Bioresour. Technol. 2015, 176, 196-202. [CrossRef] [PubMed]

117. Kim, H.M.; Wi, S.G.; Jung, S.; Song, Y.; Bae, H.-J. Efficient approach for bioethanol production from red seaweed Gelidium amansii. Bioresour. Technol. 2015, 175, 128-134. [CrossRef] [PubMed]

118. Jung, H.; Baek, G.; Kim, J.; Shin, S.G.; Lee, C. Mild-temperature thermochemical pretreatment of green macroalgal biomass: Effects on solubilization, methanation, and microbial community structure. Bioresour. Technol. 2016, 199, 326-335. [CrossRef] [PubMed]

119. Vivekanand, V.; Eijsink, V.G.H.; Horn, S.J. Biogas production from the brown seaweed Saccharina latissima: Thermal pretreatment and codigestion with wheat straw. J. Appl. Phycol. 2012, 24, 1295-1301. [CrossRef] 
120. Romagnoli, F.; Pastare, L.; Sabūnas, A.; Bālina, K.; Blumberga, D. Effects of pre-treatment on Biochemical Methane Potential (BMP) testing using Baltic Sea Fucus vesiculosus feedstock. Biomass Bioenergy 2017, 105, 23-31. [CrossRef]

121. Vázquez-Delfín, E.; Robledo, D.; Freile-Pelegrín, Y. Microwave-assisted extraction of the Carrageenan from Hypnea musciformis (Cystocloniaceae, Rhodophyta). J. Appl. Phycol. 2014, 26, 901-907. [CrossRef]

122. Mandal, V.; Mohan, Y.; Hemalatha, S. Microwave Assisted Extraction-An Innovative and Promising Extraction Tool for Medicinal Plant Research. Pharmacogn. Rev. 2007, 1, 7-18.

123. Kostas, E.T.; Beneroso, D.; Robinson, J.P. The application of microwave heating in bioenergy: A review on the microwave pre-treatment and upgrading technologies for biomass. Renew. Sustain. Energy Rev. 2017, 77, 12-27. [CrossRef]

124. Sousa, A.M.M.; Alves, V.D.; Morais, S.; Delerue-Matos, C.; Gonçalves, M.P. Agar extraction from integrated multitrophic aquacultured Gracilaria vermiculophylla: Evaluation of a microwave-assisted process using response surface methodology. Bioresour. Technol. 2010, 101, 3258-3267. [CrossRef] [PubMed]

125. Rodriguez-Jasso, R.M.; Mussatto, S.I.; Pastrana, L.; Aguilar, C.N.; Teixeira, J.A. Microwave-assisted extraction of sulfated polysaccharides (fucoidan) from brown seaweed. Carbohydr. Polym. 2011, 86, 1137-1144. [CrossRef]

126. Yuan, Y.; Xu, X.; Jing, C.; Zou, P.; Zhang, C.; Li, Y. Microwave assisted hydrothermal extraction of polysaccharides from Ulva prolifera: Functional properties and bioactivities. Carbohydr. Polym. 2018, 181, 902-910. [CrossRef] [PubMed]

127. Quitain, A.T.; Kai, T.; Sasaki, M.; Goto, M. Supercritical Carbon Dioxide Extraction of Fucoxanthin from Undaria pinnatifida. J. Agric. Food Chem. 2013, 61, 5792-5797. [CrossRef] [PubMed]

128. Quitain, A.T.; Kai, T.; Sasaki, M.; Goto, M. Microwave-hydrothermal extraction and degradation of fucoidan from supercritical carbon dioxide deoiled Undaria pinnatifida. Ind. Eng. Chem. Res. 2013, 52, 7940-7946. [CrossRef]

129. Meinita, M.D.N.; Marhaeni, B.; Winanto, T.; Jeong, G.-T.; Khan, M.N.A.; Hong, Y.-K. Comparison of agarophytes (Gelidium, Gracilaria, and Gracilariopsis) as potential resources for bioethanol production. J. Appl. Phycol. 2013, 25, 1957-1961. [CrossRef]

130. Park, J.-H.; Hong, J.-Y.; Jang, H.C.; Oh, S.G.; Kim, S.-H.; Yoon, J.-J.; Kim, Y.J. Use of Gelidium amansii as a promising resource for bioethanol: A practical approach for continuous dilute-acid hydrolysis and fermentation. Bioresour. Technol. 2012, 108, 83-88. [CrossRef] [PubMed]

131. Tsubaki, S.; Oono, K.; Onda, A.; Yanagisawa, K.; Azuma, J. Comparative decomposition kinetics of neutral monosaccharides by microwave and induction heating treatments. Carbohydr. Res. 2013, 375, 1-4. [CrossRef] [PubMed]

132. Yuan, Y.; Macquarrie, D.J. Microwave Assisted Acid Hydrolysis of Brown Seaweed Ascophyllum nodosum for Bioethanol Production and Characterization of Alga Residue. ACS Sustain. Chem. Eng. 2015, 3, 1359-1365. [CrossRef]

133. Teh, Y.Y.; Lee, K.T.; Chen, W.-H.; Lin, S.-C.; Sheen, H.-K.; Tan, I.S. Dilute sulfuric acid hydrolysis of red macroalgae Eucheuma denticulatum with microwave-assisted heating for biochar production and sugar recovery. Bioresour. Technol. 2017, 246, 20-27. [CrossRef] [PubMed]

134. Monlau, F.; Sambusiti, C.; Barakat, A.; Quéméneur, M.; Trably, E.; Steyer, J.-P.P.; Carrère, H. Do furanic and phenolic compounds of lignocellulosic and algae biomass hydrolyzate inhibit anaerobic mixed cultures? A comprehensive review. Biotechnol. Adv. 2014, 32, 934-951. [CrossRef] [PubMed]

135. Almeida, J.R.M.; Bertilsson, M.; Gorwa-Grauslund, M.F.; Gorsich, S.; Lidén, G. Metabolic effects of furaldehydes and impacts on biotechnological processes. Appl. Microbiol. Biotechnol. 2009, 82, 625-638. [CrossRef] [PubMed]

136. Yun, E.J.; Kim, H.T.; Cho, K.M.; Yu, S.; Kim, S.; Choi, I.-G.; Kim, K.H. Pretreatment and saccharification of red macroalgae to produce fermentable sugars. Bioresour. Technol. 2016, 199, 311-318. [CrossRef] [PubMed]

137. Schultz-Jensen, N.; Leipold, F.; Bindslev, H.; Thomsen, A.B. Plasma-Assisted Pretreatment of Wheat Straw. Appl. Biochem. Biotechnol. 2011, 163, 558-572. [CrossRef] [PubMed] 
138. Beltrán-Heredia, J.; Torregrosa, J.; García, J.; Domínguez, J.R.; Tierno, J.C. Degradation of olive mill wastewater by the combination of Fenton's reagent and ozonation processes with an aerobic biological treatment. Water Sci. Technol. 2001, 44, 103-108. [CrossRef] [PubMed]

139. Vanegas, C.; Hernon, A.; Bartlett, J. Influence of Chemical, Mechanical, and Thermal Pretreatment on the Release of Macromolecules from Two Irish Seaweed Species. Sep. Sci. Technol. 2014, 49, 30-38. [CrossRef]

140. Jmel, M.A.; Anders, N.; Yahmed, N.B.; Schmitz, C.; Marzouki, M.N.; Spiess, A.; Smaali, I. Variations in Physicochemical Properties and Bioconversion Efficiency of Ulva lactuca Polysaccharides after Different Biomass Pretreatment Techniques. Appl. Biochem. Biotechnol. 2018, 184, 777-793. [CrossRef] [PubMed]

141. Wi, S.G.; Kim, H.J.; Mahadevan, S.A.; Yang, D.-J.; Bae, H.-J. The potential value of the seaweed Ceylon moss (Gelidium amansii) as an alternative bioenergy resource. Bioresour. Technol. 2009, 100, 6658-6660. [CrossRef] [PubMed]

142. Pezoa-Conte, R.; Leyton, A.; Anugwom, I.; von Schoultz, S.; Paranko, J.; Mäki-Arvela, P.; Willför, S.; Muszyński, M.; Nowicki, J.; Lienqueo, M.E.; et al. Deconstruction of the green alga Ulva rigida in ionic liquids: Closing the mass balance. Algal Res. 2015, 12, 262-273. [CrossRef]

143. Mazumdar, S.; Lee, J.; Oh, M.-K. Microbial production of 2,3 butanediol from seaweed hydrolysate using metabolically engineered Escherichia coli. Bioresour. Technol. 2013, 136, 329-336. [CrossRef] [PubMed]

144. Yahmed, N.B.; Carrere, H.; Marzouki, M.N.; Smaali, I. Enhancement of biogas production from Ulva sp. by using solid-state fermentation as biological pretreatment. Algal Res. 2017, 27, 206-214. [CrossRef]

145. Schiener, P.; Stanley, M.S.; Black, K.D.; Green, D.H. Assessment of saccharification and fermentation of brown seaweeds to identify the seasonal effect on bioethanol production. J. Appl. Phycol. 2016, 28, 3009-3020. [CrossRef]

146. Barbot, Y.N.; Falk, H.M.; Benz, R. Thermo-acidic pretreatment of marine brown algae Fucus vesiculosus to increase methane production-a disposal principle for macroalgae waste from beaches. J. Appl. Phycol. 2015, 27, 601-609. [CrossRef]

147. Jard, G.; Dumas, C.; Delgenes, J.P.; Marfaing, H.; Sialve, B.; Steyer, J.P.; Carrère, H. Effect of thermochemical pretreatment on the solubilization and anaerobic biodegradability of the red macroalga Palmaria palmata. Biochem. Eng. J. 2013, 79, 253-258. [CrossRef]

148. Barbot, Y.N.; Thomsen, L.; Benz, R. Thermo-acidic pretreatment of beach macroalgae from rügen to optimize biomethane production-double benefit with simultaneous bioenergy production and improvement of local beach and waste management. Mar. Drugs 2015, 13, 5681-5705. [CrossRef] [PubMed]

149. Mutripah, S.; Meinita, M.D.N.; Kang, J.-Y.; Jeong, G.-T.; Susanto, A.B.; Prabowo, R.E.; Hong, Y.-K.; Dyah, M.; Meinita, N.; Kang, J.-Y.; et al. Bioethanol production from the hydrolysate of Palmaria palmata using sulfuric acid and fermentation with brewer's yeast. J. Appl. Phycol. 2014, 26, 687-693. [CrossRef]

150. Ye Lee, J.; Li, P.; Lee, J.; Ryu, H.J.; Oh, K.K. Ethanol production from Saccharina japonica using an optimized extremely low acid pretreatment followed by simultaneous saccharification and fermentation. Bioresour. Technol. 2013, 127, 119-125. [CrossRef] [PubMed]

151. Morimoto, M.; Takatori, M.; Hayashi, T.; Mori, D.; Takashima, O.; Yoshida, S.; Sato, K.; Kawamoto, H.; Tamura, J.; Izawa, H.; et al. Depolymerization of sulfated polysaccharides under hydrothermal conditions. Carbohydr. Res. 2014, 384, 56-60. [CrossRef] [PubMed]

152. Holme, H.K.; Lindmo, K.; Kristiansen, A.; Smidsrød, O. Thermal depolymerization of alginate in the solid state. Carbohydr. Polym. 2003, 54, 431-438. [CrossRef]

153. Chen, S.-T.; Tsai, Y.-P.; Ciou, J.-H.; Huang, Z.-Y.; Lin, W.-C.; Shiu, H. Study on saccharification techniques of alga waste harvested from a eutrophic water body for the transformation of ethanol. Renew. Energy 2017, 101, 311-315. [CrossRef]

154. Jeong, G.-T.; Park, D.-H. Production of Sugars and Levulinic Acid from Marine Biomass Gelidium amansii. Appl. Biochem. Biotechnol. 2010, 161, 41-52. [CrossRef] [PubMed]

155. Dandikas, V.; Heuwinkel, H.; Lichti, F.; Drewes, J.E.; Koch, K. Correlation between biogas yield and chemical composition of energy crops. Bioresour. Technol. 2014, 174, 316-320. [CrossRef] [PubMed]

156. Dandikas, V.; Heuwinkel, H.; Lichti, F.; Eckl, T.; Drewes, J.E.; Koch, K. Correlation between hydrolysis rate constant and chemical composition of energy crops. Renew. Energy 2018, 118, 34-42. [CrossRef]

157. Gao, L.; Li, D.; Gao, F.; Liu, Z.; Hou, Y.; Chen, S.; Zhang, D. Hydroxyl radical-aided thermal pretreatment of algal biomass for enhanced biodegradability. Biotechnol Biofuels 2015, 8. [CrossRef] [PubMed] 
158. Li, Y.; Cui, J.; Zhang, G.; Liu, Z.; Guan, H.; Hwang, H.; Aker, W.G.; Wang, P. Optimization study on the hydrogen peroxide pretreatment and production of bioethanol from seaweed Ulva prolifera biomass. Bioresour. Technol. 2016, 214, 144-149. [CrossRef] [PubMed]

159. Perez, C.M.T.; Pajares, I.G.; Alcantara, V.A.; Simbahan, J.F. Bacterial laminarinase for application in ethanol production from brown algae Sargassum sp. using halotolerant yeast. Biofuel Res. J. 2018, 17, 792-797. [CrossRef]

160. Hou, X.; Hansen, J.H.; Bjerre, A.-B. Integrated bioethanol and protein production from brown seaweed Laminaria digitata. Bioresour. Technol. 2015, 197, 310-317. [CrossRef] [PubMed]

161. Ra, C.H.; Kim, S.-K.; Hun Ra, C.; Kim, S.-K.; Ra, C.H.; Kim, S.-K.; Hun Ra, C.; Kim, S.-K. Optimization of Pretreatment Conditions and Use of a Two-stage Fermentation Process for the Production of Ethanol from Seaweed, Saccharina japonica. Biotechnol. Bioprocess Eng. 2013, 18, 715-720. [CrossRef]

162. Karray, R.; Hamza, M.; Sayadi, S. Production and characterization of enzymatic cocktail produced by Aspergillus niger using green macroalgae as nitrogen source and its application in the pre-treatment for biogas production from Ulva rigida. Bioresour. Technol. 2016, 216, 622-628. [CrossRef] [PubMed]

163. Karray, R.; Karray, F.; Loukil, S.; Mhiri, N.; Sayadi, S. Anaerobic co-digestion of Tunisian green macroalgae Ulva rigida with sugar industry wastewater for biogas and methane production enhancement. Waste Manag. 2017, 61, 171-178. [CrossRef] [PubMed]

164. Pham, T.N.; Um, Y.; Yoon, H.H. Pretreatment of macroalgae for volatile fatty acid production. Bioresour. Technol. 2013, 146, 754-757. [CrossRef] [PubMed]

165. Owens, L.; Busico-Salcedo, N. Vibrio harveyi: Pretty Problems in Paradise. In The Biology of Vibrios; Thompson, F.L., Austin, B., Swings, J., Eds.; American Society of Microbiology: Washington, DC, USA, 2006; pp. 266-280, ISBN 9781555815714.

166. Tapia-Tussell, R.; Avila-Arias, J.; Domínguez Maldonado, J.; Valero, D.; Olguin-Maciel, E.; Pérez-Brito, D.; Alzate-Gaviria, L. Biological Pretreatment of Mexican Caribbean Macroalgae Consortiums Using Bm-2 Strain (Trametes hirsuta) and Its Enzymatic Broth to Improve Biomethane Potential. Energies 2018, 11, 494. [CrossRef]

167. Qin, H.-M.; Xu, P.; Guo, Q.; Cheng, X.; Gao, D.; Sun, D.; Zhu, Z.; Lu, F. Biochemical characterization of a novel ulvan lyase from Pseudoalteromonas sp. strain PLSV. RSC Adv. 2018, 8, 2610-2615. [CrossRef]

168. Ghanbarzadeh, M.; Golmoradizadeh, A.; Homaei, A. Carrageenans and carrageenases: Versatile polysaccharides and promising marine enzymes. Phytochem. Rev. 2018, 17, 535-571. [CrossRef]

169. Williams, A.G.; Withers, S.; Sutherland, A.D. The potential of bacteria isolated from ruminal contents of seaweed-eating North Ronaldsay sheep to hydrolyse seaweed components and produce methane by anaerobic digestion in vitro. Microb. Biotechnol. 2013, 6, 45-52. [CrossRef] [PubMed]

170. Moen, E.; Horn, S.; Østgaard, K. Biological degradation of Ascophyllum nodosum. J. Appl. Phycol. 1997, 9, 347-357. [CrossRef]

171. Moen, E.; Horn, S.; Østgaard, K. Alginate degradation during anaerobic digestion of Laminaria hyperborea stipes. J. Appl. Phycol. 1997, 9, 157-166. [CrossRef]

172. Marquez, G.P.B.; Takeuchi, H.; Hasegawa, T. Biogas Production of Biologically and Chemically-pretreated Seaweed, Ulva spp., under Different Conditions: Freshwater and Thalassic. J. Japan Inst. Energy 2015, 94, 1066-1073. [CrossRef]

173. Lefebvre, O.; Moletta, R. Treatment of organic pollution in industrial saline wastewater: A literature review. Water Res. 2006, 40, 3671-3682. [CrossRef] [PubMed]

174. Chen, Y.; Cheng, J.J.; Creamer, K.S. Inhibition of anaerobic digestion process: A review. Bioresour. Technol. 2008, 99, 4044-4064. [CrossRef] [PubMed]

175. Chen, W.H.; Han, S.K.; Sung, S. Sodium inhibition of thermophilic methanogens. J. Environ. Eng. 2003, 129, 506-512. [CrossRef]

176. Ramakrishnan, B.; Kumaraswamy, S.; Mallick, K.; Adhya, T.K.; Rao, V.R.; Sethunathan, N. Effect of various anionic species on net methane production in flooded rice soils. World J. Microbiol. Biotechnol. 1998, 14, 743-749. [CrossRef]

177. El-Dessouky, H.T.; Ettouney, H.M. Fundamentals of Salt Water Desalination; Elsevier: Amsterdam, The Netherlands, 2002; ISBN 978-0-444-50810-2.

178. Roberts, K.P.; Heaven, S.; Banks, C.J. Quantification of methane losses from the acclimatisation of anaerobic digestion to marine salt concentrations. Renew. Energy 2016, 86, 497-506. [CrossRef] 
179. Savithramma, N.; Linga Rao, M.; Venkateswarlu, P. Isolation and Identification of Phenolic Compounds from Boswellia ovalifoliolata Bal. and Henry and Their Free Radical Scavenger Activity. Int. J. Drug Deliv. Technol. 2014, 4, 14-21. [CrossRef]

180. Pérez, M.J.; Falqué, E.; Domínguez, H. Antimicrobial Action of Compounds from Marine Seaweed. Mar. Drugs 2016, 14, 52. [CrossRef] [PubMed]

181. Holdt, S.; Kraan, S. Bioactive compounds in seaweed: Functional food applications and legislation. J. Appl. Phycol. 2011, 23, 543-597. [CrossRef]

182. Le Lann, K.; Jegou, C.; Stiger-Pouvreau, V. Effect of different conditioning treatments on total phenolic content and antioxidant activities in two Sargassacean species: Comparison of the frondose Sargassum muticum (Yendo) Fensholt and the cylindrical Bifurcaria bifurcata R. Ross. Phycol. Res. 2008, 56, 238-245. [CrossRef]

183. Li, Y.-X.; Wijesekara, I.; Li, Y.; Kim, S.-K. Phlorotannins as bioactive agents from brown algae. Process Biochem. 2011, 46, 2219-2224. [CrossRef]

184. Shannon, E.; Abu-Ghannam, N. Antibacterial Derivatives of Marine Algae: An Overview of Pharmacological Mechanisms and Applications. Mar. Drugs 2016, 14, 81. [CrossRef] [PubMed]

185. Tanniou, A.; Vandanjon, L.; Incera, M.; Leon, E.S.; Husa, V.; Le Grand, J.; Nicolas, J.L.; Poupart, N.; Kervarec, N.; Engelen, A.; et al. Assessment of the spatial variability of phenolic contents and associated bioactivities in the invasive alga Sargassum muticum sampled along its European range from Norway to Portugal. J. Appl. Phycol. 2014, 26, 1215-1230. [CrossRef]

186. Hierholtzer, A.; Chatellard, L.; Kierans, M.; Akunna, J.C.C.; Collier, P.J.J. The impact and mode of action of phenolic compounds extracted from brown seaweed on mixed anaerobic microbial cultures. J. Appl. Microbiol. 2013, 114, 964-973. [CrossRef] [PubMed]

187. Lordan, S.; Smyth, T.J.; Soler-Vila, A.; Stanton, C.; Ross, R.P. The $\alpha$-amylase and $\alpha$-glucosidase inhibitory effects of Irish seaweed extracts. Food Chem. 2013, 141, 2170-2176. [CrossRef] [PubMed]

188. Austin, C.; Stewart, D.; Allwood, J.W.; McDougall, G.J. Extracts from the edible seaweed, Ascophyllum nodosum, inhibit lipase activity in vitro: Contributions of phenolic and polysaccharide components. Food Funct. 2018, 9, 502-510. [CrossRef] [PubMed]

189. Tabassum, M.R.; Xia, A.; Murphy, J.D. Seasonal variation of chemical composition and biomethane production from the brown seaweed Ascophyllum nodosum. Bioresour. Technol. 2016, 216, 219-226. [CrossRef] [PubMed]

190. Tierney, M.S.; Smyth, T.J.; Rai, D.K.; Soler-Vila, A.; Croft, A.K.; Brunton, N. Enrichment of polyphenol contents and antioxidant activities of Irish brown macroalgae using food-friendly techniques based on polarity and molecular size. Food Chem. 2013, 139, 753-761. [CrossRef] [PubMed]

191. Boisvert, C.; Beaulieu, L.; Bonnet, C.; Pelletier, É. Assessment of the Antioxidant and Antibacterial Activities of Three Species of Edible Seaweeds. J. Food Biochem. 2015, 39, 377-387. [CrossRef]

192. Yuan, Y.; Zhang, J.; Fan, J.; Clark, J.; Shen, P.; Li, Y.; Zhang, C. Microwave assisted extraction of phenolic compounds from four economic brown macroalgae species and evaluation of their antioxidant activities and inhibitory effects on $\alpha$-amylase, $\alpha$-glucosidase, pancreatic lipase and tyrosinase. Food Res. Int. 2018, 113, 288-297. [CrossRef] [PubMed]

193. Tedesco, S.; Stokes, J. Valorisation to biogas of macroalgal waste streams: A circular approach to bioproducts and bioenergy in Ireland. Chem. Pap. 2017, 71, 721-728. [CrossRef] [PubMed]

194. Andrade, L.R.; Salgado, L.T.; Farina, M.; Pereira, M.S.; Mourão, P.A.S.; Amado Filho, G.M. Ultrastructure of acidic polysaccharides from the cell walls of brown algae. J. Struct. Biol. 2004, 145, 216-225. [CrossRef] [PubMed]

195. Strezov, A.; Nonova, T. Environmental Monitoring of Heavy Metals in Bulgarian Black Sea Green Algae. Environ. Monit. Assess. 2005, 105, 99-110. [CrossRef] [PubMed]

196. Akcali, I.; Kucuksezgin, F. A biomonitoring study: Heavy metals in macroalgae from eastern Aegean coastal areas. Mar. Pollut. Bull. 2011, 62, 637-645. [CrossRef] [PubMed]

197. Chen, J.L.; Ortiz, R.; Steele, T.W.J.; Stuckey, D.C. Toxicants inhibiting anaerobic digestion: A review. Biotechnol. Adv. 2014, 32, 1523-1534. [CrossRef] [PubMed]

198. Nkemka, V.N.; Murto, M. Evaluation of biogas production from seaweed in batch tests and in UASB reactors combined with the removal of heavy metals. J. Environ. Manage. 2010, 91, 1573-1579. [CrossRef] [PubMed]

199. Nkemka, V.N.; Murto, M. Exploring strategies for seaweed hydrolysis: Effect on methane potential and heavy metal mobilisation. Process Biochem. 2012, 47, 2523-2526. [CrossRef] 
200. Shobana, S.; Kumar, G.; Bakonyi, P.; Saratale, G.D.; Al-Muhtaseb, A.H.; Nemestóthy, N.; Bélafi-Bakó, K.; $\mathrm{Xia}, \mathrm{A}$. A review on the biomass pretreatment and inhibitor removal methods as key-steps towards efficient macroalgae-based biohydrogen production. Bioresour. Technol. 2017, 244, 1341-1348. [CrossRef] [PubMed]

201. Persson, P.; Andersson, J.; Gorton, L.; Larsson, S.; Nilvebrant, N.O.; Jönsson, L.J. Effect of different forms of alkali treatment on specific fermentation inhibitors and on the fermentability of lignocellulose hydrolysates for production of fuel ethanol. J. Agric. Food Chem. 2002, 50, 5318-5325. [CrossRef] [PubMed]

(C) 2018 by the authors. Licensee MDPI, Basel, Switzerland. This article is an open access article distributed under the terms and conditions of the Creative Commons Attribution (CC BY) license (http://creativecommons.org/licenses/by/4.0/). 